\title{
Turbulence measurements suggest high rates of new production over the shelf edge in the northeastern North Sea during summer
}

\author{
Jørgen Bendtsen $^{1}$ and Katherine Richardson ${ }^{2}$ \\ ${ }^{1}$ ClimateLab, Symbion Science Park, Copenhagen, 2100 O, Denmark \\ ${ }^{2}$ Center for Macroecology, Evolution and Climate, Natural History Museum of Denmark, University of Copenhagen, \\ Copenhagen, 2100 O, Denmark
}

Correspondence: Jørgen Bendtsen (jb@climatelab.dk)

Received: 22 August 2018 - Discussion started: 7 September 2018

Revised: 24 November 2018 - Accepted: 27 November 2018 - Published: 10 December 2018

\begin{abstract}
New production, i.e. that driven by allochthonous nutrient inputs, is the only form of primary production that can lead to net increases in organic material and is, therefore, important for understanding energy flow in marine ecosystems. The spatial distribution of new production is generally, however, not well known. Using data collected in July 2016, we analyse the potential for vertical mixing to support new production in the upper layers of the northeastern portion of the North Sea. Relatively large (up to $>0.5 \mathrm{mmol} \mathrm{N} \mathrm{m}^{-2} \mathrm{~d}^{-1}$ ) nitrate fluxes due to turbulent vertical mixing into the euphotic zone were found at some stations over the shelf edge, while low values $(<$ $0.1 \mathrm{mmol} \mathrm{N} \mathrm{m}^{-2} \mathrm{~d}^{-1}$ ) were found in the deeper open area north of the shelf edge. The low vertical mixing rates (dissipation rates of turbulent kinetic energy below $10^{-8} \mathrm{~W} \mathrm{~kg}^{-1}$, corresponding to vertical turbulent diffusion coefficients of $10^{-6}-10^{-5} \mathrm{~m}^{2} \mathrm{~s}^{-1}$ ) implied $f$ ratios of $<0.02$ in the open waters north of the shelf edge. In the shallow $(<50 \mathrm{~m})$ southern and central part of the study area, inorganic nutrients were low and nitrate undetectable, suggesting negligible new production here, despite relatively high concentrations of chlorophyll $a$ being found in the bottom layer. Thus, high rates of new production seem to be concentrated around the shelf-edge zone and in association with localized features exhibiting enhanced vertical mixing. We find that the nutricline depth is significantly deeper at the shelf edge and interference with increased mixing in this deeper depth range can explain the increased diapycnal nitrate fluxes. Overall, this suggests that the shelf-edge zone may be the major nutrient supplier to the euphotic zone in this area during the period of summer stratification.
\end{abstract}

\section{Introduction}

New production (NP), i.e. primary production (PP) based on inorganic nutrients recently introduced to a system, balances net losses of organic material in the euphotic layer when considered over longer periods (Dugdale and Goering, 1967). Net loss of biomass from the surface layer may be due to sinking phytoplankton or transfer to, and subsequent losses from, higher trophic levels such that this cycle between nutrient input, PP, and remineralization of organic matter constitutes an organic biological pump in the upper ocean (Volk and Hoffert, 1985). In addition to NP, total PP is comprised of photosynthesis driven by nutrients recycled within the system itself. The ratio of NP to total PP is referred to as the $f$ ratio (Eppley and Peterson, 1979). This ratio is known to vary both seasonally and spatially.

Given that NP can lead to a net increase in organic material, its occurrence can be expected to have important consequences for food webs and the distribution of marine organisms. Scott et al. (2010) analysed the distribution of marine mammals and seabirds in the northwestern North Sea, and they found the distribution of these organisms to be best explained by the presence of a subsurface chlorophyll maximum (SCM). They furthermore speculated that bathymetric features induced vertical mixing that could bring nutrients to depths containing the chlorophyll peak, which then could lead to localized NP. This potential link between localized increased NP in subsurface layers and the highest trophic levels may, therefore, be an important feature in ecosystem functioning. The distribution of NP, especially over small spatial scales, is however not well understood. The purpose of this study, therefore, was to describe the potential for NP based 
on the vertical mixing of nutrients into the euphotic zone to occur in the northeastern North Sea, a highly productive temperate ocean region. The summer season was chosen for the study as this region is thermally stratified at this time and surface waters characterized by low or undetectable concentrations of inorganic nutrients and low phytoplankton biomass. Thus, it is generally assumed that little NP is occurring in these waters at this time.

The northeastern North Sea is characterized by the transition from a relatively shallow southern region (depth $\sim 40 \mathrm{~m}$ ) across a shelf edge (depth $\sim 80-130 \mathrm{~m}$ ) towards the deep (> $400 \mathrm{~m}$ ) Norwegian Trench leading into Skagerrak (Fig. 1). The general cyclonic circulation is characterized by inflow from the Atlantic along the shelf edge, either from mainly wind-driven inflow between the Shetland and Orkney islands or from transports along the Norwegian Trench (Winther and Johannessen, 2006). Outflow takes place along the Norwegian coast, partly as less saline water masses in the Norwegian Coastal Current, and with an estimated net transport of about $1 \mathrm{~Sv}$ (sverdrup unit) in either direction (Danielssen et al., 1990). The relatively large cyclonic flow has also been found in model studies (Winther and Johannessen, 2006; Pätsch et al., 2017) where current speeds along the northeastern shelf edge towards the Skagerrak intensify (Holt and Proctor, 2008) and are found to be associated with a large eddy activity (Røed and Fossum, 2004). This dynamic area was chosen as the study area as it is a potential location for increased vertical mixing and nutrient transport due to, for example, eddy activity, breaking internal waves, and upwelling at the shelf edge.

A large part of the central and northern North Sea becomes stratified during the summer season with an SCM between $\sim 20$ and $40 \mathrm{~m}$ depth. Richardson et al. (2000) found that a significant amount of PP occurs at the SCM and argued that much of this could be NP supported by fortnightly tidally driven input of nutrient-rich deep water to the SCM. Fernand et al. (2013) found that up to $60 \%$ of PP took place in the SCM in the central and northern North Sea during the summer. Those researchers also reported a distinct SCM in the northern North Sea where the depth was larger than $\sim 40 \mathrm{~m}$, i.e. areas where tidally induced mixing cannot break the stratified water column. The northern North Sea is relatively productive during the summer season with PP levels of $\sim 0.5$ $0.9 \mathrm{~g} \mathrm{C} \mathrm{m}^{-2} \mathrm{~d}^{-1}$ (Weston et al., 2005; Fernand et al., 2013). However, few studies have been made of PP at the northern shelf edge and the distribution of NP is unknown.

Shelf areas, in general, constitute an important link between the large reservoirs of dissolved substances in the open ocean, and coastal water masses and shelf processes play an important role in global cycles of nutrients, oxygen, and carbon (Gattuso et al., 1998). Transport across the shelf edge brings nutrient-rich deep-water masses into more shallow and well-mixed areas and stimulates production above the shelf. Various cross-shelf transport processes can facilitate this exchange (Brink, 2012); thus, different exchange pro- (a)
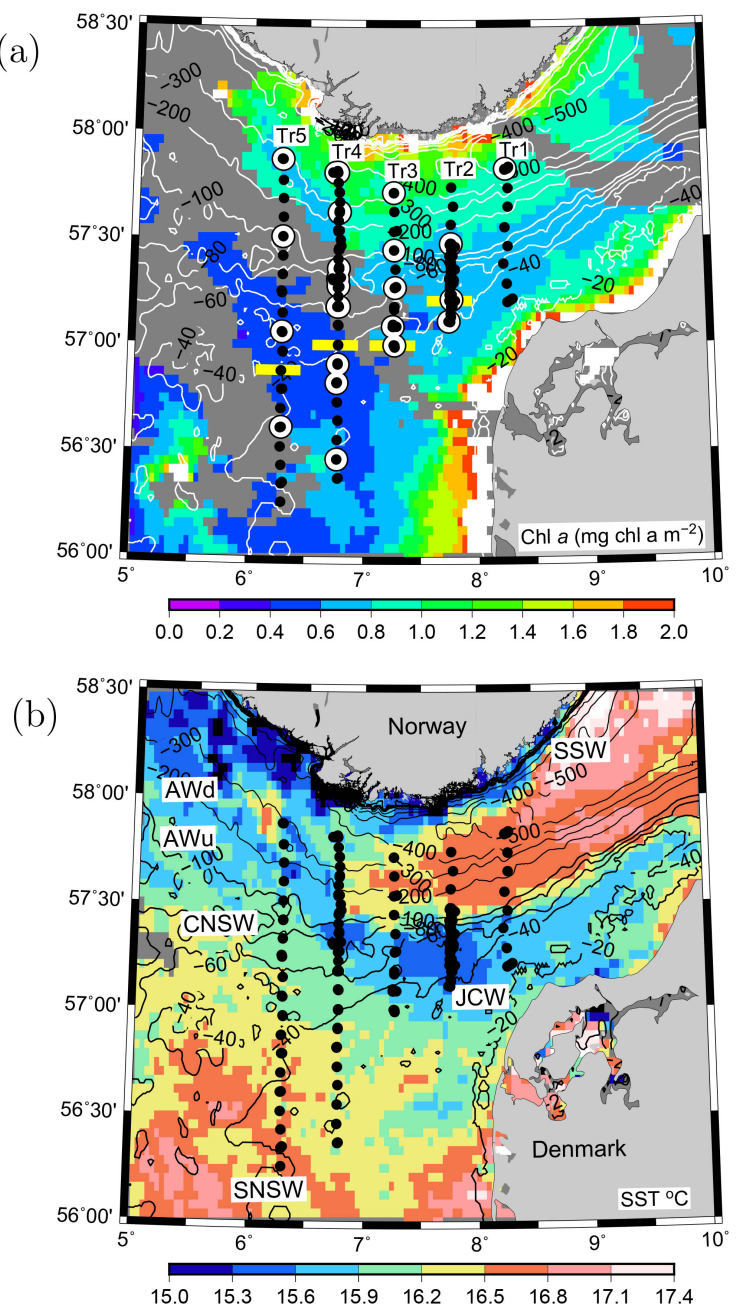

Figure 1. VERMIX station map of the five transects in the northeastern North Sea overlaid on (a) surface chlorophyll $a$ $\left(\mathrm{mg} \mathrm{chl} \mathrm{m}{ }^{-3}\right)$ and $(\mathbf{b})$ sea surface temperature $\left({ }^{\circ} \mathrm{C}\right)$ from MODIS satellite images ( $4 \mathrm{~km}$ resolution) obtained on 20 July 2016 (clouds are shown in dark grey). (a) CTD stations (bullets) and stations where ${ }^{14} \mathrm{C}$ incubations for primary production were used for estimating photosynthetic parameters in the area (white circles) along the five transects $(\operatorname{Tr} 1-5)$. Horizontal yellow bars (Tr2-5) show the separation between nitrate-deplete and nitrate-replete areas. Water masses in the area are indicated (see text). Bathymetry is contoured in metres.

cesses may dominate in different shelf-edge regions. However, shelf-edge areas share common dynamical features due to their relatively steep bathymetric slopes and the separation between coastal and open-ocean water masses. Therefore, the conditions in the northeastern North Sea may be representative of similar shelf-edge regions not directly exposed to the open-ocean basins.

Here, we analyse the physical and biological processes affecting PP and NP during the stratified summer period across the shelf edge in the northeastern North Sea based on data 
collected during the VERMIX cruise in July 2016. First, we describe the distribution of water masses, nutrients, and vertical mixing in the area. Then, we present results from PP incubations and, based on averaged representative photosynthetic parameters, calculate PP for the whole study area. Nitrate fluxes and NP are calculated and compared with PP to derive $f$ ratios. Finally, the implications for NP in the North Sea are discussed.

\section{Methods}

\subsection{Study area and hydrographic measurements}

The VERMIX study covered an area around the shelf edge in the northeastern North Sea from the shallow shelf area (depth $<50 \mathrm{~m})$ across the western part of the Norwegian trench $(\sim 500 \mathrm{~m})$ towards the coast of Norway (Fig. 1a). In this study, we define the shelf-edge zone as being where depths are between 80 and $130 \mathrm{~m}$ and refer to areas south and north of this zone as the shallow shelf area $(<80 \mathrm{~m})$ and the area off the shelf-edge zone $(>130 \mathrm{~m})$, towards Norway, respectively.

The cruise was carried out on board R/V Dana (Technical University of Denmark) during the period 12-31 July 2016. Stations were placed along five transects between 56.2 and $57.8^{\circ} \mathrm{N}$ and along $8.25^{\circ} \mathrm{E}(\operatorname{Tr} 1), 7.75^{\circ} \mathrm{E}(\operatorname{Tr} 2), 7.25^{\circ} \mathrm{E}(\operatorname{Tr} 3)$, $6.75^{\circ} \mathrm{E}(\operatorname{Tr} 4)$, and $6.25^{\circ} \mathrm{E}(\mathrm{Tr} 5)$ (i.e. $\sim 25 \mathrm{~km}$ between transects). Wind and light conditions were typical for the period, with windy conditions during the first week (along $\operatorname{Tr} 1$ and $\operatorname{Tr} 2$ with wind speeds up to $20 \mathrm{~m} \mathrm{~s}^{-1}$ ) and relatively calm conditions during the rest of the cruise ( $\operatorname{Tr} 2-5)$. In total, 132 stations were sampled along the transects with a general distance between stations of $10 \mathrm{~km}$, and at sections along $\operatorname{Tr} 2$ and $\operatorname{Tr} 4$ this distance was decreased down to $\sim 1 \mathrm{~km}$. Measurements along these two transects were made several times during the cruise to examine temporal variability. Measurements over 22-36 h were made at two time series stations (T1, T2) located at $\operatorname{Tr} 2$ and $\operatorname{Tr} 4$, respectively. Hydrographic measurements of conductivity, temperature, and depth (CTD) were made with a Seabird SBE911 plus system, including two sets of temperature, conductivity, and oxygen sensors (SBE43) and equipped with a SCUFA (selfcontained underwater fluorescence apparatus) fluorometer, a photosynthetically available radiation (PAR) sensor (Licor), and 12 Niskin bottles $(30 \mathrm{~L})$ for water sampling. All salinity values are reported as practical salinity $\left(S_{\mathrm{P}}\right)$ and referred to as salinity $(S)$, and TEOS-10 (Thermodynamic Equation of SeaWater 2010) (IOC et al., 2010) was applied for calculating properties of seawater.

\subsection{Measurements of turbulence and microstructure}

Micro-scale turbulence was measured with a loose-tethered free-fall Rockland Scientific International (RSI) VMP-250 microstructure vertical profiler equipped with two shear probes: a FP07 thermistor and a micro-conductivity sensor. The microstructure of temperature and salinity only supported the analysis of shear-induced turbulence and is not discussed further here. The profiler was also equipped with a CT (conductivity and temperature) and pressure sensor (JFE Advantech). The JFE CTD data were binned in $0.1 \mathrm{dbar}$, and the conductivity sensor was aligned with temperature by a delay of $0.14 \mathrm{~s}$. Microstructure measurements were made at $512 \mathrm{~Hz}$ and stored at $64 \mathrm{~Hz}$, and the CT sensor operated at $16 \mathrm{~Hz}$. Turbulence profiles were obtained while the ship was freely drifting. In total, 253 casts down to about $5 \mathrm{~m}$ from the bottom, or to a maximum depth of $200 \mathrm{~m}$ above deeper areas, were made during the cruise. Every cast provided two shear measurements and the dissipation rate $(\varepsilon)$ of turbulent kinetic energy (TKE) was calculated with software provided by Rockland Scientific. The dissipation of TKE was estimated from below $10 \mathrm{~m}$ depth in order to exclude possible disturbances from the ship (depth of ship was $5.7 \mathrm{~m}$ ), and it was analysed in bins of $8 \mathrm{~s}$ with $50 \%$ overlap, corresponding to a resolution of $\sim 3 \mathrm{~m}$, following the method described by Wolk et al. (2002) and revised by Lueck (2016).

The uncertainty and short-term temporal variability in the calculated $\varepsilon$ values were assessed from a time series station (T1) at $\operatorname{Tr} 2$ where $\varepsilon$ values were calculated from 107 casts carried out in three sequences over a $22 \mathrm{~h}$ period (Supplement). In general, there was good accordance between estimates of $\varepsilon$ obtained from the two sensors and the errordistribution, defined from the difference of the logarithm (to the base 10 and in units of $\mathrm{W} \mathrm{kg}^{-1}$ ) between the two estimates, had an absolute standard deviation of 0.14 (Fig. S1 in the Supplement). In order for measurements to be included in the analysis, we applied the criterion that the difference between the measurements made by the two sensors on a single profile should be less than 3 times the absolute deviation. This only led to the removal of a few pairs of $\varepsilon$ from the data set. Short-term variation at $\mathrm{T} 1$ was also found to be relatively small and temporal changes between subsequent casts were considered to have little influence on the calculated $\varepsilon$ values (time series analysis in Supplement). Therefore, $\varepsilon$ values were, in general, derived from a single cast between the relatively closely spaced stations, and the $\varepsilon$ value obtained by averaging the calculated value from the two shear probes was reported.

The vertical turbulent diffusion coefficient $\left(k_{\mathrm{V}}\right)$ was estimated from the dissipation rate of TKE (Osborn, 1980):

$k_{\mathrm{v}}=\Gamma \frac{\varepsilon}{N^{2}}$,

with a mixing efficiency $(\Gamma)$ and the Brunt-Väisälä frequency $\left(N^{2}\right)$ determined by linear regression of density $(\rho)$ with depth at $10 \mathrm{~m}$ intervals:

$N^{2}=-\frac{g}{\rho_{0}} \frac{\partial \rho}{\partial z}$ 
where $\rho_{0}$ is a reference density $\left(1027 \mathrm{~kg} \mathrm{~m}^{-3}\right)$ and $g$ is the gravitational acceleration.

The mixing efficiency, $\Gamma$, is here assumed to be constant and equal to 0.2 , and this is within the range of $\Gamma \leq 0.20$ suggested by Osborn (1980). The value of 0.2 is supported by numerical studies when the turbulent intensity, defined by $R e_{b}=\varepsilon /\left(v N^{2}\right)$ where $v$ is the molecular viscosity, is within the range 7-100 (Shih et al., 2005), and the model by Bouffard and Boegman (2013), also validated against field data, finds the valid range to be between 20 and 400 . Outside this mixing regime, the mixing efficiency is less than 0.2 . We apply the range of Bouffard et al. (2013), and this implies that our calculated diffusion coefficients with a constant mixing efficiency of 0.2 are valid in the range between $0.5 \times 10^{-7}$ and $1.0 \times 10^{-4} \mathrm{~m}^{2} \mathrm{~s}^{-1}$ (we use $v=1.2 \times 10^{-6} \mathrm{~m}^{2} \mathrm{~s}^{-1}$ ). This range encompasses the data used for calculating vertical nitrate fluxes in the euphotic zone in our study.

\subsection{Measurements of nutrients and chlorophyll $a$}

Water samples were taken at CTD stations from standard depths $(5,10,30,40,60,100$, and $200 \mathrm{~m}$ and close to the bottom). In addition, a sample from the depth (i.e. peak) of the SCM was sampled. At some stations, a distinct second chlorophyll peak or "extreme" (i.e. a subsurface chlorophyll $a$ extremum, SCE) was observed above the SCM. In some cases, water for photosynthesis incubations and inorganic nutrient (nitrate, nitrite, ammonia, phosphorous, and silicate) determination was taken from these SCEs. However, in this study we refer only to subsurface samples from the SCM. Water samples for nutrient determination were tapped from the Niskin bottles and immediately frozen. The sample was subsequently thawed, filtered (Milipore Millex-GP Hydrophylic PES $0.22 \mu \mathrm{m}$ ), and analysed for nitrite, nitrate, ammonia, phosphorous, and silica by wet-chemistry methods according to Grasshoff et al. (1983) (detection limits were $0.04,0.1,0.3,0.06$, and $0.2 \mu \mathrm{M}$, respectively) at Aarhus University, Department of Bioscience. In total 649 water samples were analysed for nutrients.

Chlorophyll $a$ (GF/F filtered and extracted in $90 \%$ ethanol) was determined fluorometrically (Trilogy, Turner Designs) and used to calibrate the rosette-mounted fluorometer (chlorophyll $a$ is simply referred to as chlorophyll below). A relatively constant background fluorescence was measured in the deep profiles ( $>200 \mathrm{~m}$ ). As we see no reason for a constant distribution of chlorophyll in waters down to depths of $\sim 500 \mathrm{~m}$, we considered this fluorescence to be generated by material other than chlorophyll. Therefore, the fluorescence was averaged between 100 and $500 \mathrm{~m}$ at a deep station on $\operatorname{Tr} 1$ $\left(57.83^{\circ} \mathrm{N}\right.$, average value of $\left.0.023 \mathrm{~V}\right)$. This relatively small value was treated as an unknown background and subtracted from the fluorescence signal $(F)$. The chlorophyll concentration (chl, $\mathrm{mg} \mathrm{chl} \mathrm{m}^{-3}$ ) was then determined from a linear regression between fluorescence $(F)$ and filtered chlorophyll samples as chl $=3.23 F-0.08\left(R^{2}=0.71, n=205\right)$.

\subsection{Calculation of photosynthetic parameters and PP}

Primary production (PP) was determined from incubations made with PAR at 12 different light intensities from 0 to $\sim 800 \mu \mathrm{E} \mathrm{m}^{-2} \mathrm{~s}^{-1}$. In total, 64 incubations were made with water sampled from the surface and/or SCM at 41 stations, and 23 and 25 incubations were selected to represent the conditions at the surface $(5 \mathrm{~m})$ and SCE, respectively (Table 1). Total PP was then calculated according to Platt et al. (1980):

$$
\begin{gathered}
\operatorname{PP}(\operatorname{chl}(z), \operatorname{PAR}(t, z))=\int_{24 \mathrm{~h}-\text { Deu }} \int_{\max }^{B}(z) \operatorname{chl}(z) \\
\left(1-\exp \left(-\operatorname{PAR}(t, z) \frac{\alpha^{B}(z)}{P_{\max }^{B}(z)}\right)\right) \\
\exp \left(-\operatorname{PAR}(t, z) \frac{\beta^{B}(z)}{P_{\max }^{B}(z)}\right) \mathrm{d} z \mathrm{~d} t
\end{gathered}
$$

where the integral is carried out in the vertical $(z)$ from the euphotic depth, Deu (assumed to be $0.1 \%$ PAR; see below), to the surface and during a $24 \mathrm{~h}$ period $(t)$. The photosynthetic parameters $\left(P_{\max }^{B}, \alpha^{B}\right.$ and $\left.\beta^{B}\right)$ were determined by fitting the photosynthesis $(P)$ vs. $E$ curves generated from the incubations to the PP expression, i.e. the terms in the integral in Eq. (3), by a non-linear Levenberg-Marquardt leastsquares routine (Press et al., 1992) and normalized with in situ chlorophyll concentration obtained from the calibrated CTD-fluorescence measurement. The case without photoinhibition, i.e. $\beta=0$ (Webb et al., 1974), in general, resulted in a poorer representation of the data (except for six incubations where the photoinhibition term was set to zero), and the incubation experiments were, therefore, analysed with the photoinhibition term included in Eq. (3). These model fits were found to be in very good accordance with the incubation data (Fig. S2). The maximum rate of photosynthesis, defined as $P_{\max }^{B}{ }^{*}$, was calculated for each $P$ vs. $E$ curve (note that $P_{\max }^{B}$ only describes the maximum PP in the case without photoinhibition).

Irradiation was measured continuously during the cruise and the hourly averaged insolation curve during the day was scaled to equal the daily averaged PAR measured from the MODIS-Aqua satellite measurements (Frouin et al., 2012) where the daily averaged PAR for July 2016 in the study area (13-28 July; $6.2-8.3^{\circ} \mathrm{E}, 56.2-58^{\circ} \mathrm{N}$ ) was $506 \mu \mathrm{E} \mathrm{m}^{-2} \mathrm{~s}^{-1}$. The vertical light extinction coefficient $\left(k_{d}\right)$ was determined by linear regression of the log-transformed PAR measurements from each CTD cast. The average value from all the CTD casts was found to be $k_{d}=0.14 \pm 0.03 \mathrm{~m}^{-1}$ (standard deviation: SD, $n=177$ ), corresponding to a $0.1 \%$ PAR depth level of $50 \mathrm{~m}$. The $0.1 \%$ PAR depth level was in this study assumed to represent the bottom of the euphotic zone.

Primary production estimates at individual sites are dependent upon the value for the maximum rate of photosynthesis $\left(P_{\max }^{B}\right)$. However, $P_{\max }^{B}$ (and all other measured photosynthetic parameters) represents the physiological condition of 
Table 1. Distribution of photosynthetic parameters. Median values and absolute median deviations (number of samples $n$ in parenthesis) of photosynthetic parameters at $5 \mathrm{~m}$ below the surface and at the SCM.

\begin{tabular}{|c|c|c|c|c|c|c|c|}
\hline $\begin{array}{l}\text { Depth } \\
\text { level }\end{array}$ & $\begin{array}{r}\text { Depth } \\
(\mathrm{m})\end{array}$ & $\begin{array}{c}P_{\max }^{B}{ }^{*} \\
\left(\mu \mathrm{gC}(\mu \mathrm{g} \mathrm{chl} \mathrm{h})^{-1}\right)\end{array}$ & $\begin{array}{r}P_{\max }^{B} \\
\left(\mu \mathrm{gC}(\mu \mathrm{g} \mathrm{chl} \mathrm{h})^{-1}\right)\end{array}$ & $\begin{array}{r}\alpha^{B} \\
10^{-2}(\mu \mathrm{g} \mathrm{C}(\mu \mathrm{g} \mathrm{chl} \mathrm{h} \\
\left.\left.\mu \mathrm{E} \mathrm{m}^{-2} \mathrm{~s}^{-1}\right)^{-1}\right)\end{array}$ & $\begin{array}{r}\beta^{B} \\
10^{-3}(\mu \mathrm{g} \mathrm{C}(\mu \mathrm{g} \mathrm{chl} \mathrm{h} \\
\left.\left.\mu \mathrm{E} \mathrm{m}^{-2} \mathrm{~s}^{-1}\right)^{-1}\right)\end{array}$ & $\begin{array}{r}E_{\max } \\
\left(\mu \mathrm{E} \mathrm{m}^{-2} \mathrm{~s}^{-1}\right)\end{array}$ & $\begin{array}{r}\mathrm{Chl} a \\
\left(\mathrm{mg} \mathrm{chl} \mathrm{m}{ }^{-3}\right)\end{array}$ \\
\hline Surface & $5.0 \pm 0.0(23)$ & $4.76 \pm 1.33(19)$ & $5.48 \pm 0.87(23)$ & $4.10 \pm 0.90(23)$ & $1.70 \pm 1.70(23)$ & $413 \pm 76(19)$ & $0.16 \pm 0.06(23)$ \\
\hline SCM & $27.0 \pm 5.0(25)$ & $1.72 \pm 0.38(24)$ & $2.33 \pm 0.64(25)$ & $2.70 \pm 0.80(25)$ & $3.00 \pm 0.90(25)$ & $192 \pm 26(24)$ & $1.67 \pm 0.73$ \\
\hline
\end{tabular}

the phytoplankton community at the time of sampling. This means that $P_{\max }^{B}$ may vary as a function of time of sampling (From et al., 2014; Richardson et al., 2016) or during different light conditions (e.g. photoinhibition). Normalization of the photosynthetic parameters with chlorophyll also represents an uncertainty in the PP estimates at individual stations as, for example, division with low chlorophyll values (e.g. some surface values were $\sim 0.1 \mathrm{mg} \mathrm{chl} \mathrm{m}^{-3}$ ) may result in large uncertainty of the normalized values due to relatively large absolute errors. This uncertainty error has been shown to potentially have a significant impact on the estimation of photosynthetic parameters (e.g. Kumari, 2005; McKee et al., 2014). Finally, the fact that photosynthetic parameters were determined from incubations carried out on only one water sample from each sampling depth represents a source of uncertainty with respect to the estimates of PP at individual stations. Therefore, in order to compare PP estimates from the stations we sampled, we applied average values (median for all stations) of photosynthetic parameters in the surface layer $(5 \mathrm{~m})$ and in the SCM in the calculation of PP. The uncertainties associated with the photosynthetic parameters are further considered in the Discussion. Surface values were assumed to represent the photosynthetic parameters in the upper $10 \mathrm{~m}$, and average values from the SCM were assumed to represent the parameters for the water column below $10 \mathrm{~m}$.

\subsection{Vertical nutrient fluxes and $f$ ratios}

Nitrate was depleted in the surface layer at almost every station and, therefore, assumed to be the limiting nutrient. This assumption was supported by the distribution of other nutrients (shown below). The nutricline was defined as the depth where nitrate equalled $0.5 \mu \mathrm{mol} \mathrm{kg}{ }^{-1}$ (the chosen threshold value had, in general, only a minor influence on the nutricline depth because nutrients were so depleted in the surface layer). In general, water samples were taken close to the nutricline, i.e. within $\pm 10 \mathrm{~m}$. However, at five stations where the nutricline was not resolved well by the sampling depths, samples from the neighbouring station (i.e. within 5-10 km) were included to increase the resolution. To minimize the uncertainty of the nutricline depth estimate associated with the linear interpolation between two neighbouring water samples, the nutricline depth was found by linear interpolation between the corresponding potential density anomalies $\left(\sigma_{\theta}\right)$ of the sample depths, and the nutricline depth was then iden- tified from the corresponding $\sigma_{\theta}$ in the CTD profile. This approach is based on the assumption that the nitrate concentrations between two water samples are more closely related to water mass characteristics than linearly to depth changes; i.e. a sharp pycnocline, not resolved by the water samples, is taken into account when the nutricline depth is estimated by this method. A comparison was made for the whole data set between nutricline depth estimates based on linear interpolation using depth and potential density anomaly levels. The difference between the two methods averaged $-1.4 \pm 2.5 \mathrm{~m}$ (SD, $n=77$ ), and the differences ranged between -9.9 and $2.4 \mathrm{~m}$. Thus, in general, the depth-level-based method resulted in a deeper nutricline $(-1.4 \mathrm{~m})$ than the applied $\sigma_{\theta}$ method

At all stations where nitrate was present $(n=73)$, the nutricline was found to be located above the depth of the $0.1 \%$ PAR light level, and, therefore, the flux of nitrate $\left(F_{\mathrm{NO}_{3}}\right)$ for NP was found by calculating the maximum flux into the euphotic zone (only transports from vertical turbulent mixing were measured; thus, contributions from vertical advection were not considered). The vertical nitrate flux $\left(F_{\mathrm{NO}_{3}}\right)$ due to turbulent mixing is defined as

$F_{\mathrm{NO}_{3}}=-k_{v} \frac{\partial \mathrm{NO}_{3}}{\partial z}=-k_{v} \frac{\partial \mathrm{NO}_{3}}{\partial \rho} \frac{\partial \rho}{\partial z}$,

where the vertical nitrate gradient is reformulated in terms of density (Sharples et al., 2007). By applying this reformulated relationship, together with the definition of the vertical turbulent diffusion coefficient in Eq. (1), an expression for the nitrate flux in terms of the measured dissipation rate of TKE becomes

$F_{\mathrm{NO}_{3}}=\frac{\Gamma \varepsilon \rho_{0}}{g} \frac{\partial \mathrm{NO}_{3}}{\partial \rho}$.

The advantage of this expression, compared to simply applying $k_{v}$ and the vertical nitrate gradient directly, is the dependence on the measured dissipation rate, rather than the derived $k_{v}$ value. The latter includes the calculation of the Brunt-Väisälä frequency; cf. Eq. (2). This term becomes close to zero in very turbulent conditions, and, thereby, $k_{v}$ becomes sensitive to rounding errors and other uncertainties in the measurements. The gradient of nitrate at a given depth was determined linearly from the nearest water sample depths. 

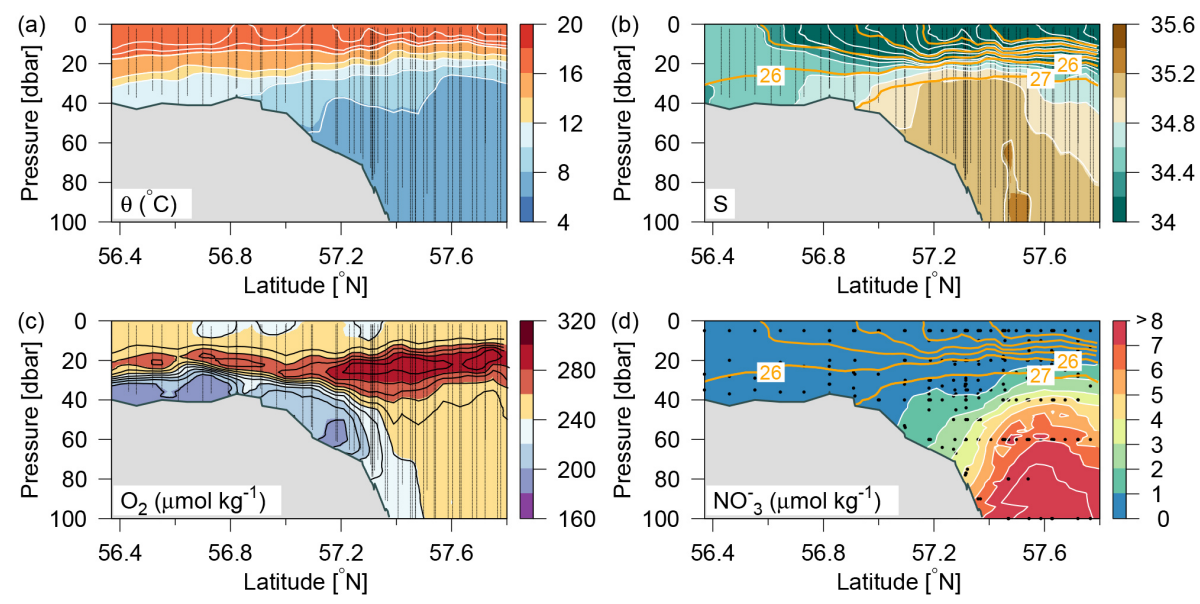

Figure 2. Distributions along $\operatorname{Tr} 4$ of (a) potential temperature $\left({ }^{\circ} \mathrm{C}\right.$; colours and white contours, additional contours above $16{ }^{\circ} \mathrm{C}$ at $0.5^{\circ} \mathrm{C}$ intervals), (b) salinity (psu; colours and white contours, additional contours between 26 and 34 at 0.5 psu intervals) and contours of potential density anomalies (intervals of $1 \mathrm{~kg} \mathrm{~m}^{-3}$; orange lines), (c) oxygen ( $\mu \mathrm{mol} \mathrm{kg}-1$; colours and black contours), and (d) nitrate ( $\mu \mathrm{mol} \mathrm{kg}-1$; colours and white contours and orange contours of potential density anomalies as in (b). Vertical lines show location of the CTD measurements.

PP was related to the vertical nitrate flux by estimating the $f$ ratio, calculated as $f=\eta_{\mathrm{N}: \mathrm{C}} F_{\mathrm{NO}_{3}} / \mathrm{PP}$, where $\eta_{\mathrm{N}: \mathrm{C}}$ is the Redfield ratio between nitrogen and carbon, i.e. $16: 106$ (Redfield et al., 1963).

\section{Results}

\subsection{Water mass distributions}

The northern North Sea is a region in which North Atlantic water transported towards the Skagerrak, water masses formed in the shallower part of the North Sea, and outflowing low-saline water from the Baltic Sea come together. Water masses and the general circulation in the area have been described by Danielssen et al. (1990), and the general water mass characteristics they identified are included in the description below. Their analysis was based on measurements obtained in the Skagerrak and the northeastern North Sea in 1990-1991.

The inflow of Atlantic water to the northern North Sea, in general, takes place between the Orkneys and Shetland, above the shelf east of the Shetlands and in the deep Norwegian channel, and the deep inflow in the Norwegian channel dominates during the summer period (Winther and Johannesen, 2006). Atlantic water masses (AWs) are characterized by salinities $>35$ and can be further delineated as upper Atlantic water (AWu; $S=35.00-35.15$ and $T=8-10^{\circ} \mathrm{C}$ ) and a slightly colder and more saline deeper Atlantic water mass (AWd; $S=35.15-35.32, T=\sim 7-10^{\circ} \mathrm{C}$, Fig. 1b). The AWd was observed on the westernmost transects ( $\operatorname{Tr} 4$ and $\operatorname{Tr} 5)$ between 100 and $300 \mathrm{~m}$ along the shelf edge. High-saline AWd was also present in the depth range $120-200 \mathrm{~m}$ on $\operatorname{Tr} 1$ (not shown). AWu was observed at the shelf edge at depths below
$60 \mathrm{~m}$ on $\operatorname{Tr} 2-5$ whereas it was found at depths below $80 \mathrm{~m}$ on $\operatorname{Tr} 1$ (Fig. 2). An upward doming of the AWu was seen to reach to $\sim 30 \mathrm{~m}$ between the shelf edge and the Norwegian coast, from where isotherms and isohalines tended to deepen towards Norway. Central North Sea water (CNSW; $S=34.80-35.0$ and $T=8-10^{\circ} \mathrm{C}$ ), a mixture of Atlantic water and Scottish coastal water, was located above AWu, and a distinct frontal zone between the two water masses was seen along the shelf edge where bottom depths ranged between 40 and $60 \mathrm{~m}$.

The influence of southern North Sea water (SNSW; $S=$ $34.50-34.8, T=8-12{ }^{\circ} \mathrm{C}$ ) (note the larger temperature interval in mid-summer than defined in Danielssen et al., 1990) and low nitrate concentrations, originating from the English Channel, was seen at the shallower stations $(<40 \mathrm{~m})$ on all transects except Tr1. Warm subsurface water between 20 and $40 \mathrm{~m}$ at $\operatorname{Tr} 1$ indicated an influence from the Jutland coastal water mass (JCW, $S=32-34$ and $T=10-15^{\circ} \mathrm{C}$ ) on this transect. The surface mixed layer varied between 5 and $15 \mathrm{~m}$ with the lowest salinities seen in the Norwegian coastal water mass $(S<28)$ and the highest surface salinities being found above the well-mixed shallow parts of the North Sea $(S \sim 34.5)$.

A distinct subsurface oxygen maximum $\left(\mathrm{O}_{2}>\right.$ $240 \mu \mathrm{mol} \mathrm{kg}^{-1}$ ) between $\sim 15$ and $35 \mathrm{~m}$ depth characterized the deeper area north of the shelf edge whereas a less well-defined maximum was present above the shelf edge and in the shallow North Sea (Fig. 2c). The bottom water $(\sim 20-60 \mathrm{~m})$ in the shallow areas exhibited relatively low oxygen concentrations, i.e. $<200 \mu \mathrm{mol} \mathrm{kg}^{-1}$. High nitrate concentrations characterized Atlantic water masses whereas very low nitrate concentrations were observed in 


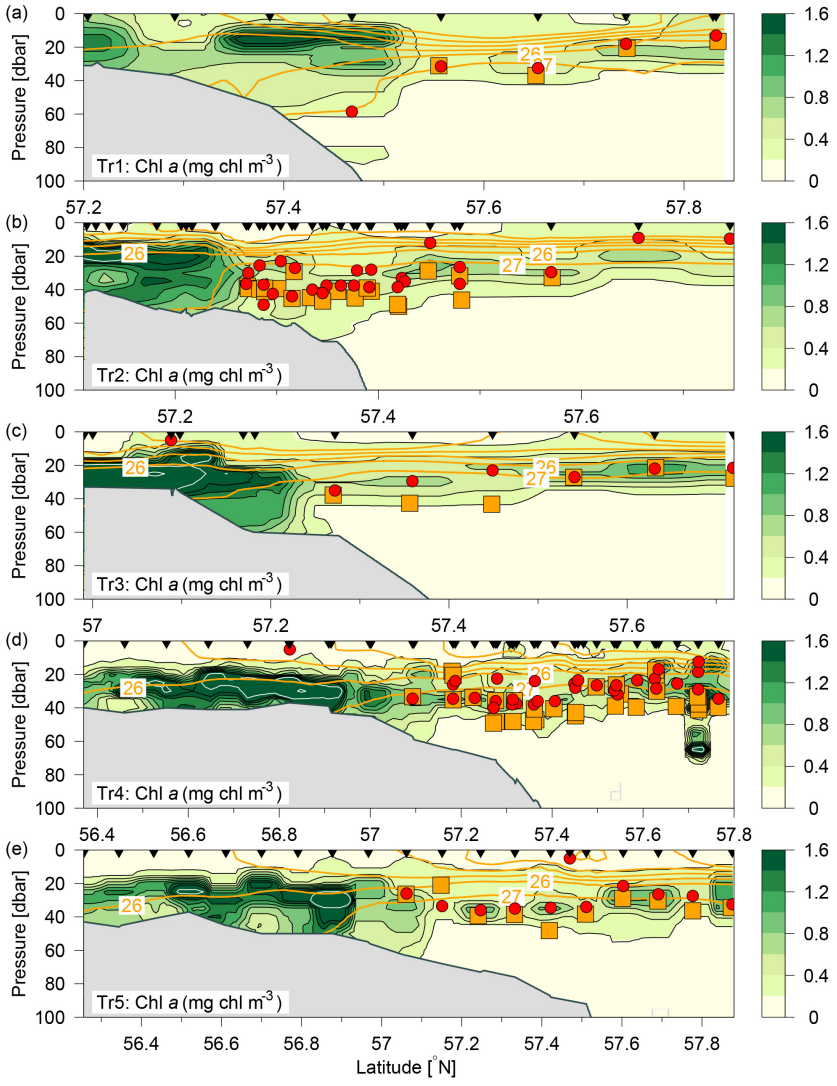

Figure 3. Distributions of chlorophyll $a\left(\mathrm{mg} \mathrm{chl} \mathrm{m}^{-3}\right.$; colours and black contours, additional white contours are shown at intervals of $2 \mathrm{mg} \mathrm{chl} \mathrm{m}^{-3}$ ) along $\operatorname{Tr} 1-\operatorname{Tr} 5$ (a-e). Nutricline depths (red bullets) and depths with maximum nitrate flux into the euphotic zone (orange squares) were calculated at each station where water samples (black triangles) and turbulence profiles were made, respectively. Contours of potential density anomalies are shown at intervals of $1 \mathrm{~kg} \mathrm{~m}^{-3}$ (orange lines). Note the different latitude-intervals in the figures.

the surface layer and above the shallow southern part of the area (Fig. 2d).

\subsection{Chlorophyll and nutrient distributions}

The subsurface chlorophyll concentrations were relatively high ( $>2 \mathrm{mg} \mathrm{chl} a \mathrm{~m}^{-3}$ ) in the shallower regions of the study area (Fig. 3). A narrow well-defined subsurface chlorophyll maximum extended from the shelf edge towards the Norwegian coast, i.e. close to the $27 \mathrm{~kg} \mathrm{~m}^{-3}$ isopycnal. The depth of the subsurface chlorophyll maximum tracked the nutricline from the shelf edge, where the nutricline was separating the nutrient-depleted surface layer from the nutrient-rich Atlantic water (Fig. 4a, b).

In general, a sharp nutricline separated the nutrient depleted surface layer from the nutrient-rich Atlantic water with nitrate concentrations above $6 \mu \mathrm{mol} \mathrm{kg}{ }^{-1}$. For example, an increase from values below the detection limit $\left(0.1 \mu \mathrm{mol}\right.$ nitrate $\left.\mathrm{kg}^{-1}\right)$ to values above $2 \mu \mathrm{mol} \mathrm{kg}{ }^{-1}$ was observed across a $5 \mathrm{~m}$ distance $(35-40 \mathrm{~m}$ depth) at the shelf edge on time series station $\mathrm{T} 2$ at $\operatorname{Tr} 4\left(57.31^{\circ} \mathrm{N}\right)$. The nutricline between CNSW and AWu was located at densityanomalies of $\sim 27.3 \mathrm{~kg} \mathrm{~m}^{-3}$, whereas the nutricline was located below the $26.5 \mathrm{~kg} \mathrm{~m}^{-3}$ isopycnal in areas influenced by SSW (Skagerrak surface water) and Norwegian coastal water masses. Thus, high nutrient concentrations were found in the cold $\left(<8^{\circ} \mathrm{C}\right)$ Atlantic water masses, and low concentrations were associated with CNSW, SNSW, and SSW.

Nitrate was not detectable at the southernmost stations south of $56.88^{\circ} \mathrm{N}$ at $\operatorname{Tr} 5,57.00^{\circ} \mathrm{N}$ at $\operatorname{Tr} 4$ and $\operatorname{Tr} 3$, and $57.21^{\circ} \mathrm{N}$ at $\operatorname{Tr} 2$, whereas the southernmost station at $\operatorname{Tr} 1$ showed detectable nitrate $\left(0.2-0.3 \mu \mathrm{mol} \mathrm{kg}^{-1}\right.$ between the surface and $30 \mathrm{~m}$ ) at the near-coastal station, likely influenced by nutrient-rich JCW (Fig. 1). Bottom samples were typically made down to $\sim 5 \mathrm{~m}$ from the bottom, i.e. within the benthic boundary layer, and, considering the relatively large turbulent diffusion coefficients in the benthic boundary layer, this supported the interpretation that no detectable nitrate was present in the water column at the southernmost stations along $\operatorname{Tr} 2-\operatorname{Tr} 5$.

The assumption that nitrate was the limiting nutrient for phytoplankton was supported by the phosphate distributions, in that the $\mathrm{N}: \mathrm{P}$ ratio was found to be significantly below Redfield (16:1) at all stations and all depths, with the exception of a few samples above the shallow area (Fig. 4c). Nitrate depletion was observed at stations above the shallow southern North Sea, where excess phosphate compared to the Redfield $\mathrm{N}$ : $\mathrm{P}$ ratio suggested significant denitrification to be occurring. There was, in general, no indication of silicate limitation because relatively high values (up to $10 \mu \mathrm{mol} \mathrm{kg}-1$ ) were observed above the nitrate-depleted shallow area and low silicate values in the deeper part were also associated with low nitrate concentrations (not shown).

\subsection{Mixing and vertical nitrate fluxes}

Dissipation of TKE was low, i.e. $<10^{-9} \mathrm{~W} \mathrm{~kg}^{-1}$, below $\sim$ $40 \mathrm{~m}$ in the deeper areas north of the shelf edge but increased by an order of magnitude above the shelf edge, where values up to $\sim 10^{-6} \mathrm{~W} \mathrm{~kg}^{-1}$ in the benthic boundary layer were recorded (Fig. 5a, b). Dissipation rates of TKE in the 20$40 \mathrm{~m}$ depth range varied between $10^{-8}-10^{-9} \mathrm{~W} \mathrm{~kg}^{-1}$ above the deeper areas and increased to $10^{-7}-10^{-8} \mathrm{~W} \mathrm{~kg}^{-1}$ above the shallow areas along $\operatorname{Tr} 2$. In the upper part of the water column, between 10 and $20 \mathrm{~m}$ depth, the dissipation rate of TKE increased to $10^{-5}-10^{-7} \mathrm{~W} \mathrm{~kg}^{-1}$ due to mixing induced by wind and waves. The distribution of the vertical turbulent diffusion coefficient showed a characteristic pattern along all transects where very low $k_{v}$ values of $<10^{-6} \mathrm{~m}^{2} \mathrm{~s}^{-1}$ between 15 and $30 \mathrm{~m}$ depth characterized the deeper open areas, i.e. around the pycnocline. Increased mixing was seen at the shelf edge and in the $\sim 10 \mathrm{~m}$ thick benthic boundary layer further south above the shallow shelf (Fig. 5c, d; note that the 

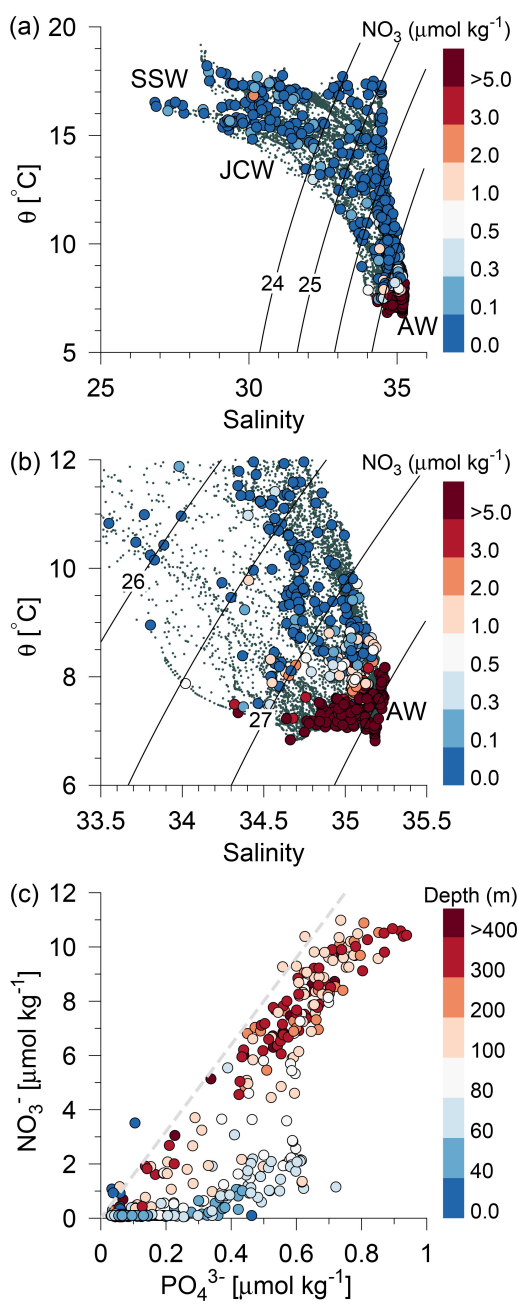

Figure 4. (a) Potential temperature-salinity diagram of all CTD measurements and (b) a high-saline subset of the measurements (small grey bullets). Water sample concentrations of nitrate are shown by large bullets in (a, b) $\left(\mu \mathrm{mol} \mathrm{kg}{ }^{-1}\right.$, colour bar). Contour lines show isopycnals of potential density anomalies, and selected water masses are indicated. (c) Nitrate vs. phosphate for all water samples. The total water depth is shown with colours (m) and the relationship $\left[\mathrm{NO}_{3}^{-}\right]=\eta_{\mathrm{N}: \mathrm{P}}\left[\mathrm{PO}_{4}^{-}\right], \eta_{\mathrm{N}: \mathrm{P}}=16: 1$, is shown by a grey dashed line.

shallow turbulence profiles on $\operatorname{Tr} 4$ did not resolve the benthic boundary layer). The highest $k_{v}$ values, i.e. $>10^{-4} \mathrm{~m}^{2} \mathrm{~s}^{-1}$, were observed at the shelf edge and in the benthic boundary layer above the shallow part of the shelf.

Vertical nitrate fluxes were calculated for all stations where both nutrients and turbulence profiles were measured. Examples are shown for four stations across the shelf edge on $\operatorname{Tr} 4$, obtained on 27 July between 14:00 and 17:30 UTC, with a station spacing of $\sim 5 \mathrm{~km}$, in an area where there is a northward increase in the depth from 82 to $122 \mathrm{~m}$ (Fig. 6). The nutricline was located at $\sim 35 \mathrm{~m}$, and this depth was relatively close to the increased mixing in the bottom bound- ary layer. Increased mixing is seen at the station located at $57.404^{\circ} \mathrm{N}$ (Fig. 6c, g), and this results here in a maximum nitrate flux to the euphotic layer of $0.3 \mathrm{mmol} \mathrm{N} \mathrm{m}^{-2} \mathrm{~d}^{-1}$ at $\sim 40 \mathrm{~m}$. In general, the maximum vertical nitrate flux into the euphotic zone in the deeper parts along the five transects was located 5-10 $\mathrm{m}$ below the nutricline (Fig. 3, orange squares), whereas the SCM was located at the nutricline (Figs. 3, 6a). Although the nitrate flux at this depth was relatively low, this showed the close relationship between SCM and nutricline depth.

\subsection{Photosynthetic parameters}

Photosynthetic parameters can vary as a function of sampling time and in situ light conditions. Therefore, in order to be able to compare the potential PP at different stations, we averaged photosynthetic parameters for the surface layer $(5 \mathrm{~m})$ and from the SCM. In total, 64 incubations were made. Fiftyeight of the incubations were fitted with the photoinhibition term, whereas six incubations did not show any significant decrease for increasing light levels. Therefore, the inhibition term was excluded in these calculations. To make the data set representative of the whole study area, incubations from the closely spaced $(1-3 \mathrm{~km})$ stations on $\operatorname{Tr} 2$ were excluded (i.e. 14 stations between the two stations shown with incubations at $\operatorname{Tr} 2$ in Fig. 1a), and, to reduce the impact from outliers, representative values are calculated as median and median absolute deviation values (Table 1).

The median chlorophyll concentrations at the surface and SCM were 0.16 and $1.68 \mathrm{mg} \mathrm{chl} a \mathrm{~m}^{-3}$, respectively. This reflected the general increase in chlorophyll with depth observed over the entire area. The chlorophyll-normalized photosynthetic parameters of the photosynthetic rate constant $\left(P_{\max }^{B}\right)$ and the slope of the PE (i.e. photosynthesis vs. irradiance) curve $\left(\alpha^{B}\right)$ in the surface layer were $5.48 \mu \mathrm{g} \mathrm{C}$ $(\mu \mathrm{g} \mathrm{chl} \mathrm{h})^{-1}$ and $0.041 \mu \mathrm{gC}\left(\mu \mathrm{g} \mathrm{chl} \mathrm{h} \mu \mathrm{E} \mathrm{m}^{-2} \mathrm{~s}^{-1}\right)^{-1}$, respectively, and the corresponding values of $P_{\max }^{B}$ and $\alpha^{B}$ at the SCM were 2.33 and 0.027 . Thus, $P_{\max }^{B}$ was significantly lower at the SCM, in general accordance with previous studies (see review in Richardson et al., 2016), whereas $\alpha^{B}$ showed a weak decrease with depth (with overlapping uncertainty intervals between the two depth levels). In general, $\alpha^{B}$ has been found to increase significantly with depth (resulting in a more efficient photosynthetic response at low light levels), and inspection of the vertical distribution showed at tendency to higher values between 15 and $25 \mathrm{~m}$ depth (i.e. 2-3e-folding depth of PAR) and lower values below $30 \mathrm{~m}$ resulting in a lower median value from SCM level. It was noted that a similar pattern of $\alpha^{B}$, with a subsurface maximum, has been observed at the European shelf in the Celtic Sea (Hickman et al., 2012).

There was a significant averaged photoinhibition $\left(\beta^{B}\right)$ at both depth levels (1.70 and $3.00\left(10^{-3} \mu \mathrm{g} \mathrm{C}\right.$ $\left.\left.\left(\mu \mathrm{E} \mathrm{m}^{-2} \mathrm{~s}^{-1} \mathrm{~h}\right)^{-1}\right)\right)$. However, the average values at these depths were not significantly different. The maximum PP 

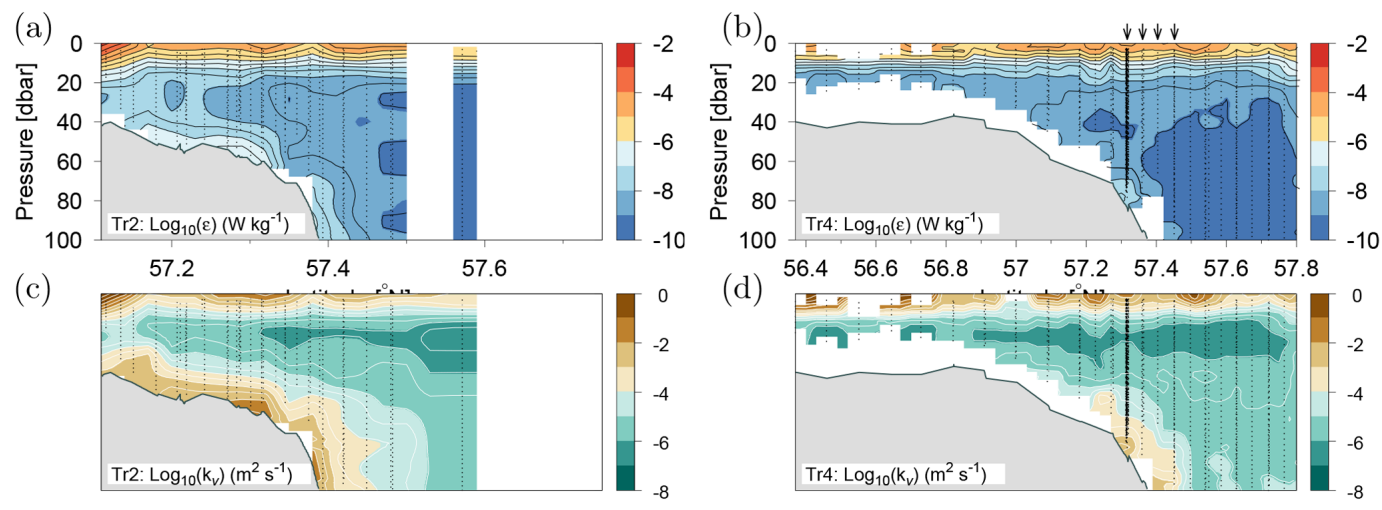

Figure 5. Turbulence measurements along $\operatorname{Tr} 2(\mathbf{a}, \mathbf{c})$ and $\operatorname{Tr} 4(\mathbf{b}, \mathbf{d})$. (a, b) Logarithm $\left(\log _{10}\right)$ of dissipation of turbulent kinetic energy $\left(\mathrm{W} \mathrm{kg}^{-1}\right)$ and $(\mathbf{c}, \mathbf{d})$ calculated vertical turbulent diffusion coefficient $\left(\mathrm{m}^{2} \mathrm{~s}^{-1}\right)$.

was characterized by $P_{\max }^{B}{ }^{*}$ values of 4.76 and $1.72 \mu \mathrm{g} \mathrm{C}$ $(\mu \mathrm{g} \mathrm{chlh})^{-1}$ at the surface and SCM, respectively, corresponding to maximum PP at PAR levels of 413 and $192 \mu \mathrm{E} \mathrm{m}^{-2} \mathrm{~s}^{-1}$. The averaged parameters for the two depth levels of $P_{\max }^{B}, \alpha^{B}$ and $\beta^{B}$ were applied for calculating PP in the water column according to Eq. (3). A comparison was made between the resulting PE curves and the maximum averaged PP from all the incubations (i.e. the $P_{\max }^{B}{ }^{*}$ and $E_{\max }$ in Table 1). These values were found to fit the averaged curves for the two depth levels within $5 \%$, and, therefore, the PE-curve-based values in Table 1 were assumed to be representative of average conditions and applied in the calculation of PP for all of the stations.

\subsection{Vertically integrated chlorophyll, PP, and NP}

The vertically integrated chlorophyll in the euphotic zone $(50 \mathrm{~m})$ showed a local maximum south of the shelf edge along all transects and a decrease in chlorophyll further south at the two westernmost transects, i.e. $\operatorname{Tr} 4$ and $\operatorname{Tr} 5$ (Fig. 7a). Relatively low values were observed in the area north of the shelf edge with the exception of an area close to Norway where high values were observed. The averaged vertically integrated chlorophyll from all stations was $29.9 \pm$ $7.8 \mathrm{mg} \mathrm{chl} a \mathrm{~m}^{-2}$ (SD, $n=128$ ).

The distribution of vertically integrated total PP showed a similar pattern with increased PP levels south of the shelf edge and a somewhat reduced PP further south at the two westernmost transects (Fig. 7b). A tendency to minimum values was observed at the shelf edge with an increasing tendency towards Norway with high PP values being observed at a few stations near the Norwegian coast. The averaged vertically integrated PP from all stations was $476 \pm$ $110 \mathrm{mg} \mathrm{C} \mathrm{m}^{-2} \mathrm{~d}^{-1}(n=128)$.

The maximum nitrate flux into the euphotic zone $\left(F_{\mathrm{NO}_{3}}\right)$ and the $f$ ratio were calculated for each station where nitrate and turbulence measurements were made and where nitrate was present in detectable concentrations. The vertical distri- bution of the maximum nitrate flux was, in general, characterized by being located below the SCM (cf. Fig. 3, Table 2). However, the horizontal distribution showed a characteristic pattern where increased fluxes and $f$ ratios were found along the shelf edge on $\operatorname{Tr} 2-\operatorname{Tr} 5$ (nitrate fluxes were not measured at the shelf edge and at shallow stations at $\operatorname{Tr} 1$ ). Increased fluxes were also observed near the Norwegian coast at $\operatorname{Tr} 1$ and $\operatorname{Tr} 4$, and low nitrate fluxes and $f$ ratios characterized the open area between the shelf edge and Norway (Fig. 7c, d).

\subsection{Distributions across the shelf edge}

A comparison of distributions of PP-related parameters across the shelf edge showed common trends over all five transects (Figs. 7, S3). Vertically integrated chlorophyll and PP were relatively low, with values of $\sim 20 \mathrm{mg} \mathrm{chl} a \mathrm{~m}^{-2}$ and $\sim 400 \mathrm{mg} \mathrm{C} \mathrm{m}^{-2} \mathrm{~d}^{-1}$, respectively, on the southernmost parts of the transects. A gradual northward increase towards maximum values (of $\sim 60 \mathrm{mg} \mathrm{chl} \mathrm{m}^{-2}$ and $>1000 \mathrm{mg} \mathrm{C} \mathrm{m}^{-2} \mathrm{~d}^{-1}$ ) was observed within a distance of $\sim 20 \mathrm{~km}$ south of the shelf edge on $\operatorname{Tr} 3-\operatorname{Tr} 5$. Transect 2 did not reach as far south of the shelf edge. This could explain the southern maximum in chlorophyll and PP at Tr2. Transect 1 was influenced by nutrient-rich JCW, and this may be the rea-

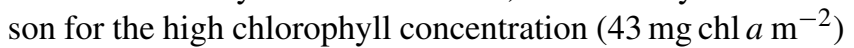
and PP (1746 $\left.\mathrm{m} \mathrm{C} \mathrm{m}^{-2} \mathrm{~d}^{-1}\right)$ at the southernmost station on this transect.

Relatively low values of $\sim 20 \mathrm{mg} \mathrm{chl} \mathrm{m}^{-2}$ and $400 \mathrm{mg} \mathrm{C} \mathrm{m}^{-2} \mathrm{~d}^{-1}$, respectively, characterized chlorophyll and PP at the shelf-edge zone. These values increased slightly towards Norway to $\sim 30 \mathrm{mgchl} a \mathrm{~m}^{-2}$ and 5$600 \mathrm{mg} \mathrm{C} \mathrm{m}^{-2} \mathrm{~d}^{-1}$, respectively. High values were observed in Norwegian coastal water masses on $\operatorname{Tr} 1$ and $\operatorname{Tr} 4$, probably due to PP being stimulated by coastal upwelling (also indicated by relatively cold Norwegian coastal surface water masses observed from satellite in Fig. 1b). Stations on $\operatorname{Tr} 2$ and $\operatorname{Tr} 4$ were visited twice within one week. Significant temporal variation in chlorophyll and PP was observed 

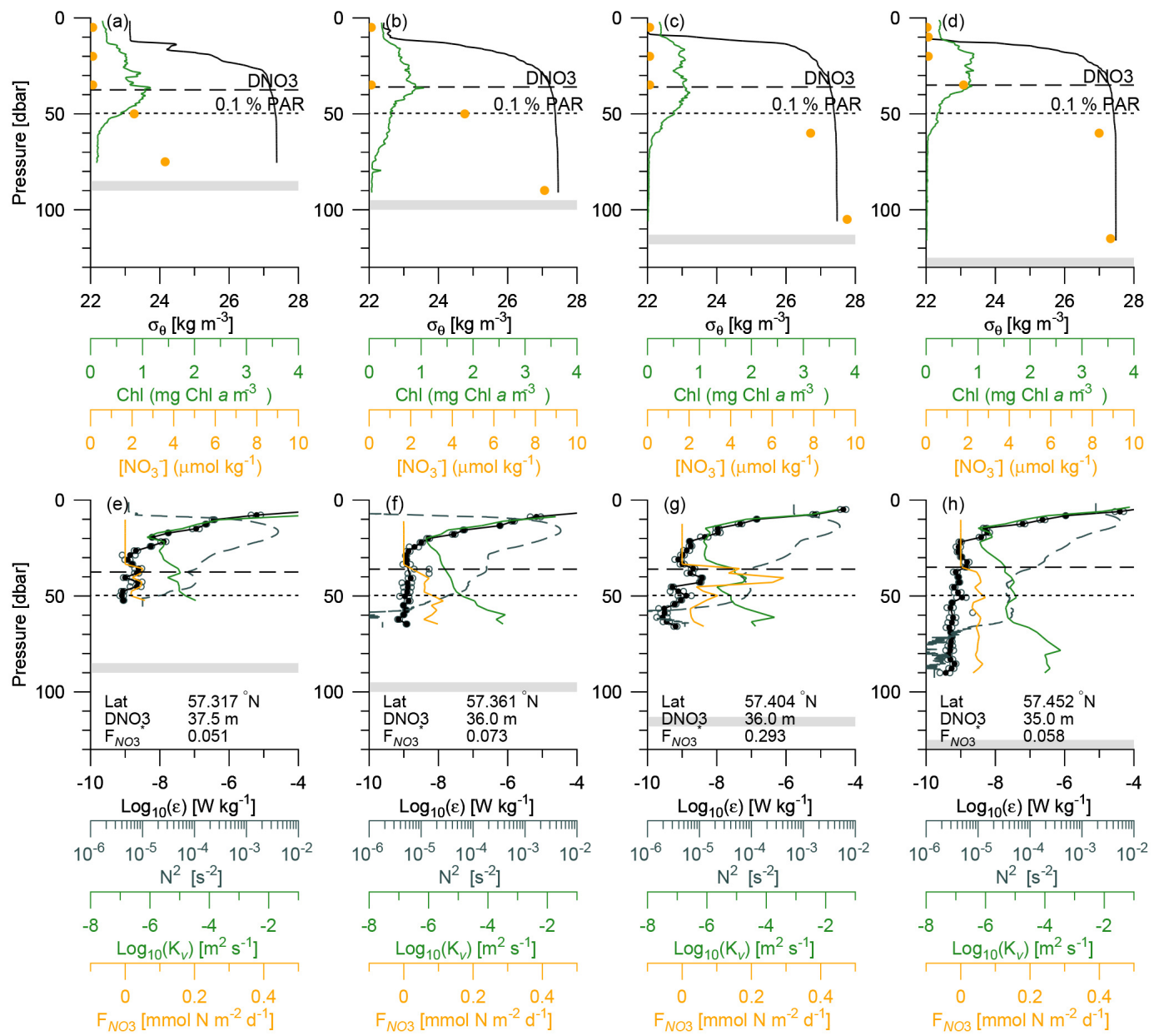

Figure 6. Vertical profiles from four stations across the shelf edge of (a-d) potential density anomaly, chlorophyll $a$, and nitrate (bullets) and (e-h) dissipation of TKE (average value and values from the two shear sensors are shown by bullets and open circles, respectively), Brunt-Väisälä frequency (dashed line), turbulent diffusion coefficient, and the vertical turbulent nitrate flux. The nutricline depth $\left(D_{\mathrm{NO} 3}\right)$ and depth of the euphotic zone ( $0.1 \%$ PAR) are shown (dashed and dotted lines), and station information of locations, $D_{\mathrm{NO}_{3}}$, and maximum $F_{\mathrm{NO}_{3}}$ to the euphotic zone are shown in the panels (e)-(h).

(Fig. S3) between samplings. Chlorophyll increased by up to $40 \%$ above the shallow area near the shelf edge and a similar increase was seen in PP. Relatively large temporal variations were also seen in these parameters in the coastal Norwegian water masses.

A nutricline could, in general, not be identified above the shallow areas south of the shelf edge except at two stations on $\operatorname{Tr} 3$ and $\operatorname{Tr} 4$ (cf. Fig. 2c, d; at both stations high nitrate concentrations of $0.9-1 \mu \mathrm{mol} \mathrm{kg}-1$ were only measured at $5 \mathrm{~m}$ while low values of $0.1-0.3 \mu \mathrm{mol} \mathrm{kg}{ }^{-1}$ were found below $10 \mathrm{~m})$. The deepest nutricline depths $(\sim 40 \mathrm{~m})$ were found near the shelf edge. Nutricline depth decreased to $\sim 20 \mathrm{~m}$ going northwards but then increased again in the coastal Norwegian water masses (Fig. 8c). Nitrate fluxes were generally very low $\left(<0.1 \mathrm{mmol} \mathrm{N} \mathrm{m}^{-2} \mathrm{~d}^{-1}\right)$ in the deeper area north of the shelf edge due to low vertical mixing in the upper $50 \mathrm{~m}$. However, the largest nutrient fluxes were seen in the shelf- edge zone and near the Norwegian coast. This resulted in $f$ ratios above 0.10 in these regions compared to $<0.02$ for the remainder of the study area (Figs. 7, S3).

The distributions were analysed across the shelf edge by dividing the stations into three depth ranges characterizing the shallow area $(50-80 \mathrm{~m})$, the shelf-edge zone $(80-130 \mathrm{~m})$, and the deep area $(>130 \mathrm{~m}$ ) (Table 2). Although the shelf edge was characterized by the largest nutrient fluxes, the averaged values were not significantly higher than observed above the deeper areas. However, the depth of the maximum flux was found to be significantly deeper $(\sim 43 \mathrm{~m})$ above the shelf edge than in the deeper area $(\sim 32 \mathrm{~m})$. This can be explained by the significantly deeper nutricline at the shelf edge $(\sim 35 \mathrm{~m})$ than observed above the deeper area $(\sim 27 \mathrm{~m})$. Distributions of vertically integrated chlorophyll and PP support the idea that minimum values are found above the shelf edge. However, the low values are not significantly different from 
Table 2. Median values and absolute median deviations of all data in three depth intervals, depth of maximum nitrate flux (Depth max $_{\text {) }}$ maximum nitrate flux into the euphotic zone $\left(\mathrm{FNO}_{\max }\right)$, depth of nutricline $\left(D_{\mathrm{NO}_{3}}\right)$, vertically integrated chlorophyll $a$ (chl $\left.{ }_{\text {int }}\right)$, and primary production (PP).

\begin{tabular}{|c|c|c|c|c|c|c|}
\hline $\begin{array}{l}\text { Depth interval } \\
(\mathrm{m})\end{array}$ & $\begin{array}{r}\text { Depth } \\
(\mathrm{m})\end{array}$ & $\begin{array}{r}\text { Depth }_{\text {max }} \\
(\mathrm{m})\end{array}$ & 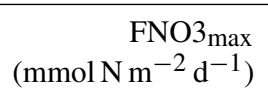 & $\begin{array}{r}D_{\mathrm{NO}_{3}} \\
(\mathrm{~m})\end{array}$ & $\begin{array}{r}\mathrm{Chl}_{\text {int }} \\
\left(\mathrm{mg} \mathrm{chl} \mathrm{m}^{-2}\right)\end{array}$ & $\left(\mathrm{mg} \mathrm{C} \mathrm{m}^{-2} \mathrm{~d}^{\mathrm{PP}}\right)$ \\
\hline $50-80$ & $65 \pm 6(25)$ & $39 \pm 3(25)$ & $0.05 \pm 0.04(25)$ & $34.5 \pm 4.5(28)$ & $34.8 \pm 13.3(69)$ & $476 \pm 138(69)$ \\
\hline $80-130$ & $97 \pm 11(18)$ & 43 & $0.11 \pm 0.07$ & $34.5 \pm 3.5(20)$ & $.9(24)$ & $41(24)$ \\
\hline$>130$ & $263 \pm 58(30)$ & $32 \pm 5(30)$ & $0.06 \pm 0.03(30)$ & $26.5 \pm 4.0$ & $26.6 \pm 4.2(35)$ & $528 \pm 101(35)$ \\
\hline
\end{tabular}

(a)

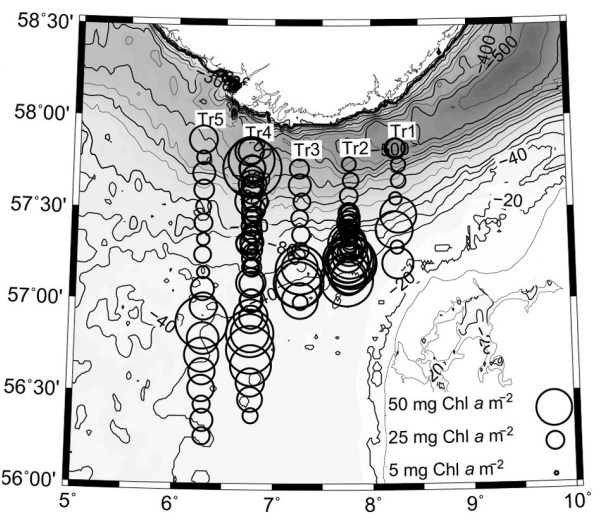

(c)

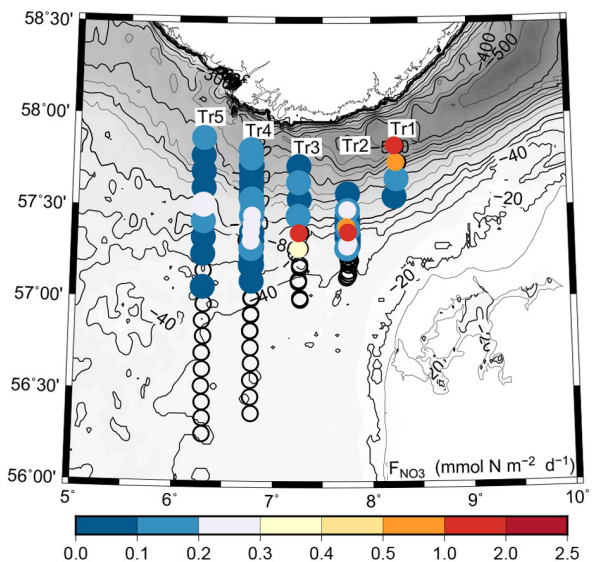

(b)

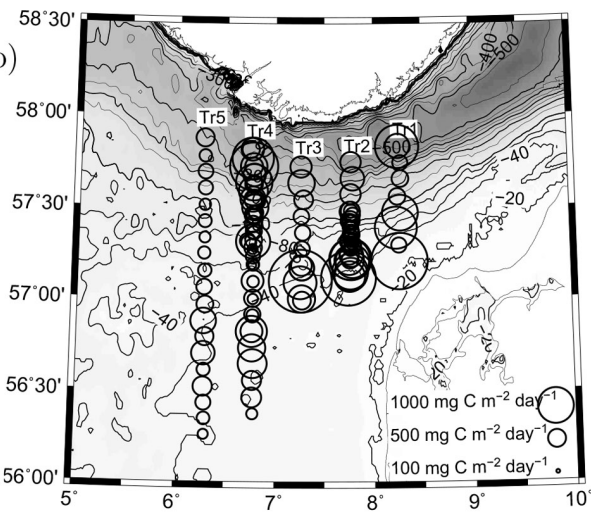

$(\mathrm{d})$

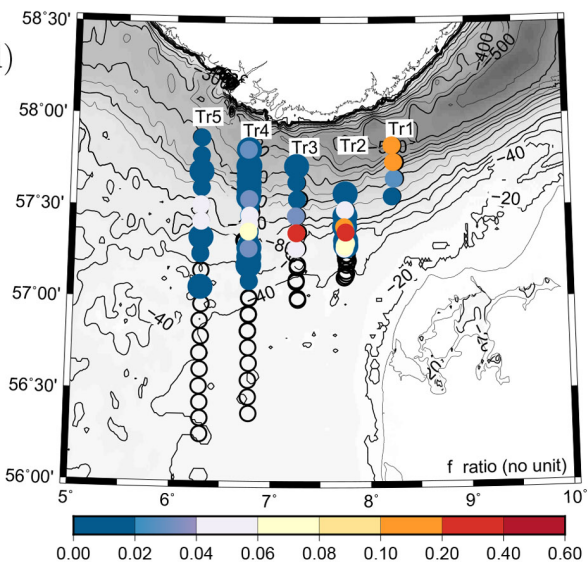

Figure 7. (a) Vertically integrated chlorophyll $a\left(\mathrm{mg} \mathrm{chl} a \mathrm{~m}^{-2}\right)$ and (b) primary production $\left(\mathrm{mg} \mathrm{C} \mathrm{m}^{-2} \mathrm{~d}^{-1}\right)$. Values are proportional to the diameter of the circles. (c) Distribution of maximum nitrate flux to the euphotic zone $\left(F_{\mathrm{NO}_{3}}, \mathrm{mmol} \mathrm{N} \mathrm{m}^{-2} \mathrm{~d}^{-1}\right)$ and (d) $f$ ratios for the euphotic zone (colours, no unit).

the larger values above the deeper and shallower part of the area.

\subsection{Temporal variability at the shelf edge}

Data were collected over $36 \mathrm{~h}$ from a time series station located on the shelf edge on $\operatorname{Tr} 4$ (depth $82 \mathrm{~m} ; 57.314^{\circ} \mathrm{N}$, $6.765^{\circ} \mathrm{E}$; from 29 July 07:07 to 30 July 19:25) where CTD casts and turbulence measurements were carried out every hour (although no turbulence measurements were made during the night at this station). Variability was related to the tidal current obtained from the barotropic OTIS model of the
North Sea (Egbert and Erofeeva, 2002). The model depth $(h)$ at the time series location was $80 \mathrm{~m}$, it considers 11 tidal constituents, its general performance has previously been validated, and a comparison was also made against tide tables for the period from Hanstholm harbour located on the Danish coast $\left(57.17^{\circ} \mathrm{N}, 8.62^{\circ} \mathrm{E}\right)$. The model result showed excellent agreement with the tidal phases. Tidal energy input was estimated from the cube of the barotropic tidal current $\left(u^{3}\right.$; e.g. Simpson and Sharples, 2012). This energy input represents the source for tidally induced vertical mixing and can be compared with turbulent mixing in the water column. 

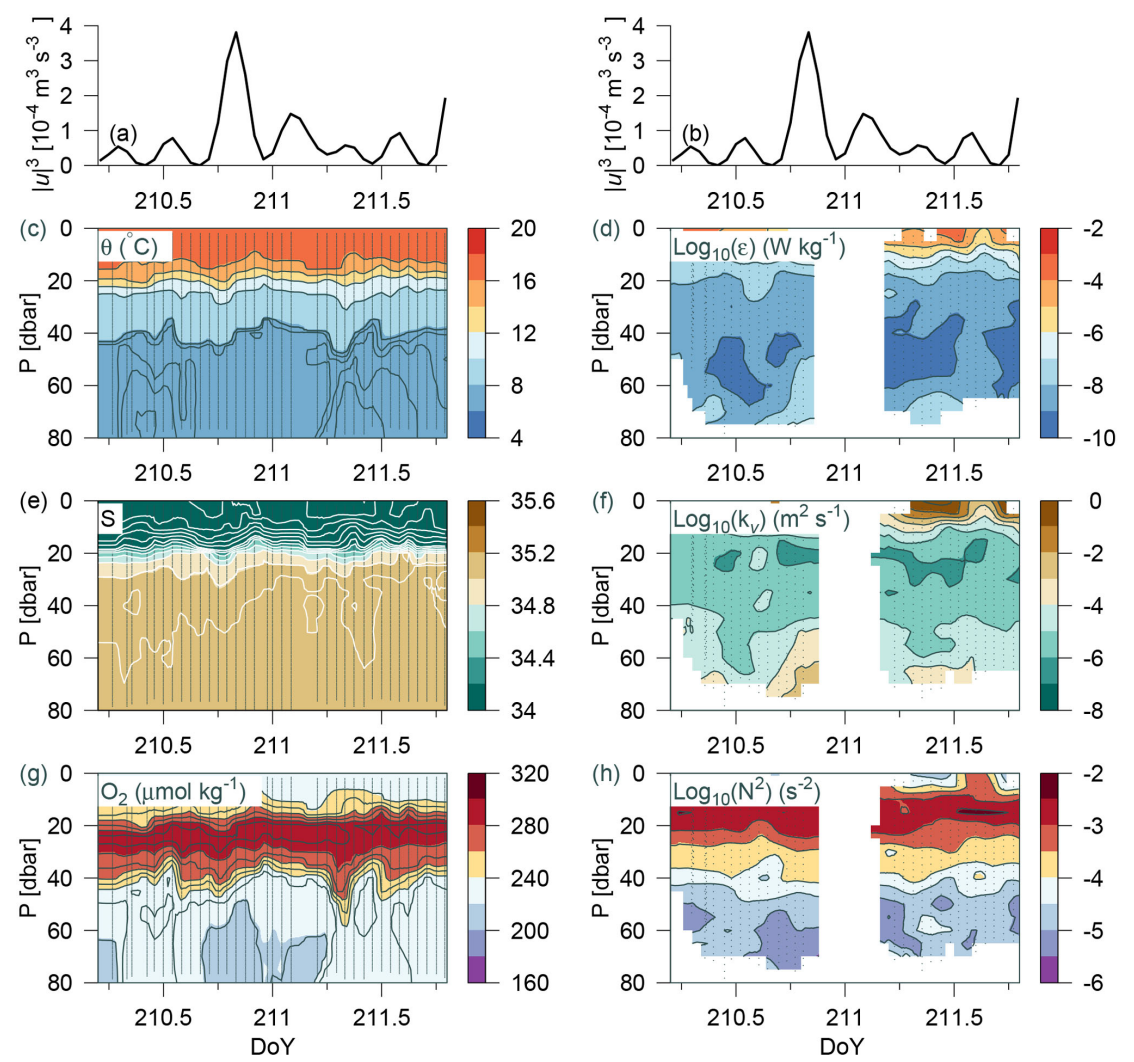

Figure 8. Time series station over $36 \mathrm{~h}$ at the shelf edge. (a, b) Tidal current speed cubed; CTD measurements in panels (c), (e), (g), and (h) of potential temperature, salinity, oxygen, and Brunt-Väisälä frequency, respectively. Turbulence measurements of (d) dissipation rate of TKE and (f) calculated vertical turbulent diffusion coefficient. Observations are shown by small grey bullets and samples for water chemistry are shown by bullets in (g).

The water column was characterized by a homogenous mixed layer in the upper 5-10 $\mathrm{m}$, a pycnocline at $\sim 20 \mathrm{~m}$, and a relatively homogenous temperature and salinity distribution below $\sim 45 \mathrm{~m}\left(\theta<8^{\circ} \mathrm{C}\right)$ (Fig. 8). A sharp nutricline between 38 and $40 \mathrm{~m}$ separated the nitrate-depleted surface layer from the nitrate-rich bottom water $(\sim 2 \mu \mathrm{mol} \mathrm{kg}-1$; not shown). An oxygen maximum layer between $20-40 \mathrm{~m}$ separated the oxygenated surface layer from the bottom layer with a relatively lower oxygen concentration. Weak temperature and salinity stratification was observed at the start and end of the period (i.e. between DoY (day of year) 210.3210.7 and 211.3-211.7), and a corresponding change was observed in the bottom oxygen concentration. The period between DoY 210.6 and 211.2 was characterized by a relatively homogenous bottom layer $(<40 \mathrm{~m})$. Increased turbulence $(\varepsilon$, $\left.k_{v}\right)$ and decreased stratification $\left(N^{2}\right)$ were also observed in this period (Fig. 8d-h). Mixing in the bottom layer increased simultaneously with tidal energy input (Fig. 8a, b). This indicated that tidal barotropic currents overlain on baroclinic currents along the shelf edge could explain the temporal variability in turbulence.

Dissipation of TKE in the bottom layer at the time of the maximum observed dissipation $(\mathrm{DoY}=210.8)$ was compa- rable with the energy input from the tides $\left(\sim 10^{-3} \mathrm{~W} \mathrm{~m}^{-2}\right)$. Additional energy for turbulence may also be provided from non-tidal currents along the shelf edge (strong eastward currents below $20 \mathrm{~m}$ were noted at the time of some of the turbulence profiles). A relatively large deepening of both $T, S$, and $\mathrm{O}_{2}$ below the pycnocline was observed between DoY 211.25-211.4. Nutrient concentrations below $60 \mathrm{~m}$ showed an increase from $2-3$ to $5-6 \mu \mathrm{mol} \mathrm{kg}{ }^{-1}$. This indicated that advection of water below the pycnocline could explain the short-term variation observed.

Thus, the observed temporal variability in water column structure and nutrient distributions at the shelf edge shows that varying mixing intensities may interfere with the bottom of the euphotic zone and, thereby, promote diapycnal nutrient fluxes and stimulate NP. The variability arises due to different physical processes, which cannot be identified in detail from the present data set. This may also explain the observed variability between stations located in the shelf-edge area (Table 2). Periods of low mixing in the euphotic zone may be followed by short periods of intense mixing. Such temporal variability is a challenge to document over a larger area. 


\section{Discussion}

The shelf edge was identified in this study as a potential area of localized NP during the stratified summer period in the northeastern North Sea. Very low nitrate fluxes and $f$ ratios were estimated for most of the open water extending northwards from the shelf edge towards Norway. Likewise, little or no NP was estimated to be occurring in the nitratedepleted shallow reaches of the southern North Sea. Previous studies have shown that shelf-edge areas can be productive regions, for example characterized by increased fishing activity (Sharples et al., 2013). In relation to the observations reported by Sharples et al. (2013), we speculate that the abundance of fish in this area could be related to a localized increase in NP relative to surrounding waters. It can also be noted that the northeastern shelf-edge area is characterized by increased fish species diversity (ICES, 2008), suggesting that the introduction of new nutrients to the euphotic region of the water column identified for this region may be influencing both food webs and ecosystem structure.

Localized NP at the shelf edge will also influence the oxygen concentration in subsurface water masses (Fig. 2). This can have a direct influence on ambient water with relatively low oxygen above the shallow shelf and influence conditions further downstream, where water masses from the shelf edge eventually reach the North Sea-Baltic Sea transition zone and contribute to bottom water ventilation in more eutrophic areas (Bendtsen et al., 2009).

The possible occurrence of localized NP also implies that physical processes on relatively small spatial scales $(\sim 1 \mathrm{~km})$ are important for modelling NP in the area. This is in general accordance with model studies where the resolution of physical processes at high spatial scales was found to be necessary to explain observed patterns of PP in the North Sea (Skogen and Moll, 2000). Holt et al. (2012) applied a high-resolution model of the whole North Sea area and showed that nutrient transports towards the shelf area were of primary importance for understanding PP and also for assessing the impact from climate change (Holt et al., 2010). Localized NP at the shelf edge in the northeastern North Sea may be representative of the open-ocean-shallow-shelf exchange of nutrients more generally. If so, then this NP may also impact nutrient conditions above the shallow central North Sea and may explain some of the recent decadal decline in PP in this area (Capuzzo et al., 2018).

\subsection{Regenerated production above the shallow shelf}

There was no measurable nitrate in the water column at stations south of the shelf edge., i.e. an area where the whole water column was within the euphotic zone, i.e. $<50 \mathrm{~m}$ (Fig. 1a, yellow lines). This indicates that nitrate sinks, i.e. biological consumption or denitrification, exceed nitrate sources, i.e. nitrification, nitrogen fixation, or advective supply during summer months in this region. Significant nitrifi- cation may take place in the water column (Clark et al., 2008; Zehr and Kudela, 2011) or in the sediment and, as pointed out in the work of Dugdale and Goering (1967), nitrate can, in this case, not be considered as a non-regenerated nutrient form in the euphotic zone. Yool et al. (2007) estimated a global specific nitrification rate of $0.2 \mathrm{~d}^{-1}$; thus, even small concentrations of ammonium could lead to significant nitrification rates. Concentrations of ammonium were, however, very low in the nitrate-depleted area. For example, ammonium was undetectable at all nitrate-depleted stations on $\operatorname{Tr} 5$, and this indicated a relatively small contribution from nitrification in the euphotic zone. Observed nitrification rates span a large range (Yool et al., 2007), and the importance of nitrification varies between ocean regions (Clark et al., 2008; Fawcett et al., 2015). Therefore, it remains an open question whether or not significant nitrification takes place in the euphotic zone in the area.

Diazotrophy constitutes another potential source of nitrogen to the nitrate-depleted surface layer and $\mathrm{N}_{2}$ fixation has been measured in the southern North Sea at Dogger Bank (Fan et al., 2015). However, the estimated nitrogen fluxes from $\mathrm{N}_{2}$ fixation were very small compared to the relatively high PP. Increased nutrient fluxes and NP at the shelf edge could also support PP in the ambient shallow areas through isopycnal transport of dissolved organic material. A substantial fraction of dissolved organic material remineralizes on timescales of days to weeks (Bendtsen et al., 2015; Hansen and Bendtsen, 2014), and isopycnal transport of organic matter could then supply organic nitrogen from the shelf-edge zone. Both the nitrification and isopycnal supply of organic material, thus, potentially provide new nitrogen to the shallow area, and this confuses the concept of nitrate-based new versus regenerated production here. However, nitrification in the euphotic zone would be based on regenerated production and, therefore, we consider PP to be regenerated production in areas without detectable nitrate in the water column.

Recycling of organic matter above the shallow shelf could, thus, be maintained by regenerated organic matter in the water column or sediment, and we analysed whether this was in accordance with estimated carbon and nitrogen pools. The high biomass in the shallow area, indicated by chlorophyll concentrations of $\sim 2-4 \mathrm{mg} \mathrm{chl} \mathrm{m}^{-3}$ in the bottom layer, would rapidly consume a regenerated pool of inorganic nitrogen. The regenerated cycling could, in principle, originate from the winter concentration of nitrate of $\sim 6 \mathrm{mmolDIN} \mathrm{m}^{-3}$ in the area (Pätsch and Kühn, 2008). The nitrate distribution in the shallow area indicates a large denitrification ranging within $0-4 \mathrm{mmol} \mathrm{DIN} \mathrm{m}^{-3}$ (Fig. $4 \mathrm{c}$ ), and this would correspond to a pool of more than $2 \mathrm{mmol} \mathrm{DIN} \mathrm{m}^{-3}$ available for establishing the phytoplankton biomass. Denitrification rates in the sediment of 0.02 $0.1 \mathrm{mmol} \mathrm{N} \mathrm{m}^{-2} \mathrm{~d}^{-1}$ have been observed at the Dogger Bank between May and August (Fan et al., 2015), and such high rates could explain the indicated nitrate sink. Assuming a Redfield C : N molar ratio of 6.6 and a $\mathrm{C}$ : chlorophyll ratio 
of $1 \mathrm{mg} \mathrm{C} / 50 \mathrm{mg} \mathrm{chl}$, this would equal $\sim 3 \mathrm{mg} \mathrm{chl} \mathrm{m}^{-3}$; i.e. it would be in general accordance with the observed concentrations of $<1$ and $\sim 4 \mathrm{mg} \mathrm{chl} \mathrm{m}^{-3}$ in the surface and bottom layers, respectively. Relatively low oxygen concentrations in the bottom layer also suggested an active bacterial respiration (Fig. 2c) to be occurring here. Thus, regenerated production could be maintained and explained by the recycling of an initial nutrient pool from early spring.

\subsection{Photosynthetic parameters and PP}

Estimates of PP based on photosynthetic parameters from ${ }^{14} \mathrm{C}$ incubations and in situ conditions of light and chlorophyll rely on several critical assumptions, including the values used for photosynthetic parameters, the distribution of chlorophyll, light conditions, and nutrient-carbon relationships. Photosynthetic parameters from individual incubation experiments were well described by the PP model (i.e. PP described by the terms in the integrals in Eq. (3), where parameter values are taken from incubations; see Fig. S2 for examples of incubation data), so uncertainty is mainly related to the spatial and temporal variability in these parameters. Photosynthetic parameters are bulk parameters describing the physiological response of the phytoplankton community as a whole to a given a photon flux. Thus, both algae composition and actual fitness of the cells contribute to the observed range of these parameters.

The photosynthetic parameters represent the conditions of the phytoplankton community at the time of sampling. However, these may vary during the day (Richardson et al., 2016) or during different light conditions (e.g. photoinhibition). Thus, PP calculations based on spatial and temporal averaging of the photosynthetic parameters from the surface and SCM (cf. Table 1) may result in a more representative PP than obtained from photosynthetic parameters obtained from a single PP incubation.

The values reported here (Table 1) for photosynthetic parameters are comparable with those found in previous studies in the North Sea (e.g. Weston et al., 2005). The variability in the photosynthetic parameters, e.g. the uncertainty of the surface value of $P_{\max }^{B}{ }^{*}$ of $\sim \pm 30 \%$, implies a corresponding uncertainty in PP. Thus, using a common set of photosynthetic parameters implies an uncertainty even within this relatively small study area, and similar limitations would probably apply to other PP estimates for the North Sea area. These considerations illustrate that a better understanding of the distributions of photosynthetic parameters and the factors underlying these distributions is a prerequisite for improved estimates of PP on regional and larger scales. Given the uncertainties related to the determination of the absolute rate of PP at individual stations, we believe the most robust manner by which to compare PP and NP over our study area is to use constant (average) values for photosynthetic parameters for all stations.

\subsection{Nutrient fluxes and NP at the shelf-edge zone}

The largest vertical nitrate fluxes of up to > $0.5 \mathrm{mmol} \mathrm{N} \mathrm{m}^{-2} \mathrm{~d}^{-1}$ were restricted to the area above the shelf edge where increased mixing in the bottom layer intersected the nutricline within the euphotic zone. Large nitrate fluxes have been observed along the European shelf where tidally induced (Sharples et al., 2001; located in the English Channel) or wind-induced mixing (Williams et al., 2013; Celtic Sea) leads to daily averaged vertical fluxes of $1-2 \mathrm{mmol} \mathrm{N} \mathrm{m}^{-2} \mathrm{~d}^{-1}$. Significantly larger fluxes have also been observed above steep bathymetric gradients (Tweddle et al., 2013). Wind and tidal mixing may also provide energy for intensified mixing along the northeastern shelf edge in the North Sea, although the present study did not resolve the specific cause for increased mixing. Shelf-edge zones are dynamic areas where cross-shelf exchange may occur due to many different dynamic processes (Huthnance, 1995; Brink, 2012).

Mixing associated with wind and tides (e.g. Burchard and Rippeth, 2009) as well as breaking internal waves (Sharples et al., 2007, 2009) has been shown to be important for vertical nutrient fluxes in shelf areas. The specific physical processes behind increased turbulent mixing cannot be identified from the present data set. Measurements on the time series station at the shelf edge showed that increased mixing occurred in phase with the tidal energy input but also that additional energy sources likely contributed to the increased mixing, e.g. energy from non-tidal currents. Short-term variability associated with advection of ambient water masses was also observed. This could possibly be related to sub-mesoscale eddies or other transport processes occurring below the pycnocline. The time series station $\mathrm{T} 2$ at $\mathrm{Tr} 4$ showed an important feature where mixing associated with the bottom boundary layer increased and intersected the bottom of the euphotic zone. Thus, the combined effect from a deep nutricline and increased mixing provides a mechanism for increased diapycnal nutrient fluxes along the shelf edge.

Other processes may be important on the northeastern shelf edge due to the large in- and outflow of Atlantic water masses. It is interesting to note that the deepening of the nutricline from the open areas towards the shelf edge mirrors the slope of the pycnocline. Via the thermal wind equations, the slope of the pycnocline implies an increased eastward baroclinic velocity component with depth, in accordance with the general cyclonic circulation in the area. Thus, a deepening of the nutricline can potentially be explained as a dynamic response to a shelf-edge current transporting Atlantic water into the area.

The conditions across the shelf edge observed during the stratified summer season may, therefore, be considered as a stable quasi-stationary system where mixing at the shelf edge, associated with a deep nutricline and nutrient-rich bottom currents, provides nutrients to the euphotic zone stimulating localized new production in this area (Fig. 9). Isopyc- 


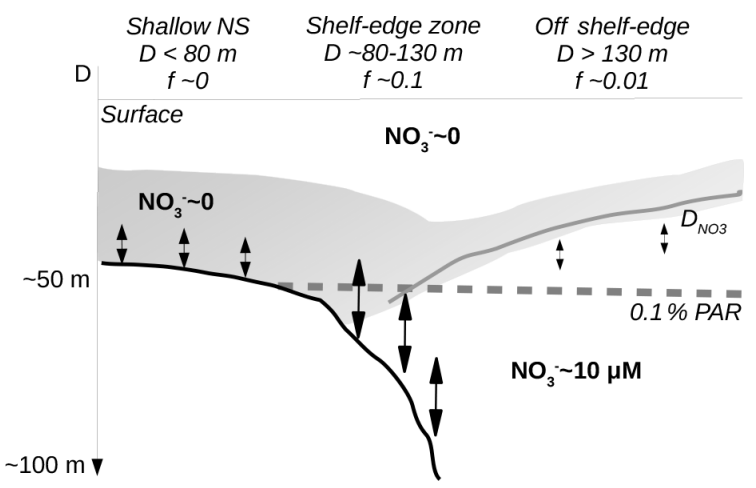

Figure 9. Sketch of conditions across the shelf-edge zone during summer. The largest $f$ ratios are found above the shelf-edge zone where the nutricline $\left(D_{\mathrm{NO}_{3}}\right)$ comes into contact with increased mixing near the bottom. Deep waters are characterized by high nitrate concentration whereas surface water and water above the shallow North Sea (NS) are nitrate depleted.

nal mixing may provide organic matter for increased regenerated production above the nitrate-depleted shallow shelf area and also, together with upwelling along the Norwegian coast, provide fresh organic material to the euphotic zone off the shelf edge towards Norway. Thus, the tendency towards increased chlorophyll concentrations and PP on either side of the shelf edge might be explained as being a result of the gradual build-up of biomass as nutrients are transported away from the shelf-edge region by isopycnal mixing. Alternatively, the tendency to low values above the shelf edge could also be explained by a larger grazing pressure above the shelf edge. Thus, a full explanation of the tendency to low chlorophyll and PP above the shelf-edge area cannot be determined from these data.

\subsection{Vertical nutrient fluxes in the euphotic zone}

The position of the SCM was closely related to the depth of the nutricline (e.g. Figs. 3 and 6) and located in the middle of the euphotic zone (average nutricline depth from all stations was $29.1 \pm 9.7 \mathrm{~m} ; n=83$ ). The maximum nitrate flux was found at depth levels between 3.4 above and $23.1 \mathrm{~m}$ below the nutricline. However, on average, it was located $6.4 \pm 7.7 \mathrm{~m}(n=73)$ below the nutricline depth. Thus, the maximum nitrate flux was within the euphotic zone but, in general, significantly below the SCM (Fig. 3). This implies that internal recycling from below the SCM towards the surface of regenerated nitrogen is necessary for maintaining the phytoplankton biomass in the upper layer. Considering the relatively low vertical mixing rates around the SCM (e.g. a turbulent diffusion coefficient of $<5 \times 10^{-5} \mathrm{~m}^{2} \mathrm{~s}^{-1}$ implies a timescale of $\sim 3$ weeks for mixing across a $10 \mathrm{~m}$ thick layer; Fig. 5), this indicates that other transport processes within the euphotic zone are important in this area. One possible mechanism could be diel vertical migration of plankton. Raven and Richardson (1984) showed the potential for diel vertical migration as an efficient strategy for phytoplankton to get access to both nutrients and light. Such a strategy might be particularly beneficial for phytoplankton in the low-mixing zone in the pycnocline north of the shelf edge (e.g. Fig. 5d at $\sim 20 \mathrm{~m}$ depth north of $57.4^{\circ} \mathrm{N}$ ), where the vertical diffusion coefficient is below $5 \times 10^{-5} \mathrm{~m}^{2} \mathrm{~s}^{-1}$ in a $\sim 20 \mathrm{~m}$ deep layer. Applying a typical swimming speed for some dinophytes of $\sim 10 \mathrm{~m} \mathrm{day}^{-1}$ across a $10 \mathrm{~m}$ deep layer in such a region implies a Peclet number $\gg 1$; thus, diel vertical migration is a potential additional nitrogen transport although this cannot be documented from our data.

\subsection{Nutrient fluxes north of the shelf edge}

Nutrient fluxes and NP increased close to the Norwegian coast (Figs. 7, S3). This was in accordance with chlorophyll estimates (Hu et al., 2012) based on daily images from the MODIS-Aqua satellite: a large algal bloom was observed 6 July (not shown) and covered the area off the southernmost part of Norway. A satellite image from 20 July (Fig. 1a) showed increased chlorophyll concentrations near the Norwegian coast, and colder sea surface temperatures along the coast also indicated influence from upwelling of subsurface water masses (Fig. 1b). Although our observations were made more than 12 nautical miles from the coast, the increased chlorophyll and PP values at $\operatorname{Tr} 1$ and $\operatorname{Tr} 4$ are likely related to these features. A tendency to a thicker chlorophyll layer around the SCM and a deeper nutricline at $\operatorname{Tr} 4$ and $\operatorname{Tr} 5$ also indicates increased production and supply of nutrients near the coast. Mixing processes along the Norwegian shelf edge may, therefore, similarly contribute to NP in the area.

\section{Conclusions}

Relatively high PP and chlorophyll concentrations of $476 \mathrm{mg} \mathrm{C} \mathrm{m}^{-2} \mathrm{~d}^{-1}$ and $30 \mathrm{mg} \mathrm{chl} \mathrm{m}^{-2}$, respectively, characterized the stratified northeastern North Sea in July 2016. The greatest values were found above the shallow shelf and near the Norwegian coast. Turbulence measurements showed maximum dissipation rates of TKE in the benthic boundary layer above the shallow shelf area and increased mixing above the shelf-edge zone, whereas very low vertical mixing rates characterized the deeper open area. Chlorophyll was concentrated in a subsurface chlorophyll maximum located near the nutricline and, on average, about $6 \mathrm{~m}$ above the depth of the maximum vertical nitrate flux in the deeper area north of the shelf edge. Chlorophyll was concentrated in the bottom layer above the shallow and nitrate-depleted shelf area. The nutricline was located significantly deeper above the shelf-edge area (depth $\sim 80-130 \mathrm{~m}$ ) than in deeper water columns. Significant NP was found above the shelf edge where, at some stations, relatively large nitrate fluxes with more than $0.5 \mathrm{mmol} \mathrm{N} \mathrm{m}^{-2} \mathrm{~d}^{-1}$ implied $f$ ratios above 0.10 . 
In contrast, very low nutrient fluxes characterized the open area above the Norwegian Trench $(f$ ratios $<0.02)$. This localized NP along the shelf edge potentially represents an important key to understanding temporal variability in the distribution of organisms (diversity), biological production, and ecosystem structure in this productive area.

Data availability. Data are archived at ICES (http://www.ices.dk/, last access date: 7 December 2018).

Supplement. The supplement related to this article is available online at: https://doi.org/10.5194/bg-15-7315-2018-supplement.

Author contributions. Measurements of primary production and turbulence were carried out by KR and JB, respectively, and both analysed the data and prepared the paper.

Competing interests. The authors declare that they have no conflict of interest.

Acknowledgements. We thank the captain and crew on-board R/V Dana for very helpful assistance and support during the cruise and Eik Ehlert Britch for technical support. Erik Askov Mousing carried out most of the PP incubations. This study was supported by funding for ship time by the Danish Centre for Marine Research. The Carlsberg foundation provided support for the turbulence instrument (CF15-0301). The Villum foundation provided support for the cruise and analysis of the measurements. Analyses were supported by Danish National Science Foundation via its support of the Center for Macroecology, Evolution, and Climate (grant no. DNRF96). Satellite-derived PAR and Chl data were obtained from the NASA Goddard Space Flight Center, Ocean Ecology Laboratory, Ocean Biology Processing Group (2014) MODIS-Aqua Ocean Color Data (https://doi.org/10.5067/AQUA/MODIS/L3M/PAR/2018 and https://doi.org/10.5067/AQUA/MODIS/L3M/CHL/2018) (last access: 5 October 2018). The paper benefitted from comments by two anonymous reviewers.

Edited by: Emilio Marañón

Reviewed by: two anonymous referees

\section{References}

Bendtsen, J., Gustafsson, K. E., Söderkvist, J., and Hansen, J. L. S.: Ventilation of bottom water in the North Sea Baltic Sea transition zone, J. Marine Syst., 75, 138-149, https://doi.org/10.1016/j.jmarsys.2008.08.006, 2009.

Bendtsen, J., Hilligsøe, K. M., Hansen, J. L. S., and Richardson, K.: Analysis of remineralisation, lability, temperature sensitivity and structural composition of organic matter from the upper ocean, Prog. Oceanogr., 130, 125-145, https://doi.org/10.1016/j.pocean.2014.10.009, 2015.
Bouffard, D. and Boegman, L.: A diapycnal diffusivity model for stratified environmental flows, Dynam. Atmos. Oceans, 61-62, 14-34, https://doi.org/10.1016/j.dynatmoce.2013.02.002, 2013.

Brink, K. H.: Cross-shelf exchange, Annu. Rev. Mar. Sci., 8, 59-78, https://doi.org/10.1146/annurev-marine-010814-015717, 2012.

Burchard, H. and Rippeth, T.: Generation of bulk shear spikes in shallow stratified tidal seas, J. Phys. Oceanogr., 39, 969-985, 2009.

Capuzzo, E., Lynam, C. P., Barry, J., Stephens, D., Forster, R. M., Greenwood, N., McQuatters-Gollop, A., Silva, T., van Leeuwen, S. M., Engelhard, G. H.: A decline in primary production in the North Sea over 25 years, associated with reductions in zooplankton abundance and fish stock recruitment, Glob. Change Biol., 24, e352-e364, https://doi.org/10.1111/gcb.13916, 2018.

Clark, D. R., Rees, A. P., and Joint, I.: Ammonium regeneration and nitrification rates in the oligotrophic Atlantic Ocean: Implications for new production estimates, Limnol. Oceanogr., 53, 5262, 2008.

Danielssen, D. S., Edler, L., Fonselius, S., Hernroth, L., Ostrowski, M., Svendsen, E., and Talpsepp, L.: Oceanographic variability in the Skagerrak and Northern Kattegat, May-June, 1990, ICES J. Mar. Sci., 54, 753-773, 1990.

Dugdale, R. C. and Goering, J. J.: Uptake of new and regenerated forms of nitrogen in primary productivity, Limnol. Oceanogr., 12, 196-206, 1967.

Egbert, G. D. and Erofeeva, S. Y.: Efficient inverse modeling of barotropic ocean tides, J. Atmos. Ocean. Tech., 19, 183-204, 2002.

Eppley, R. W. and Peterson, B. J.: Particulate organic matter flux and planktonic new production in the deep ocean, Nature, 282, 677-680, 1979.

Fan, H., Bolhuis, H., and Stal, J.: Drivers of the dynamics of diazotrophs and denitrifiers in North Sea bottom waters and sediments, Front. Microbiol., 6, 738, https://doi.org/10.3389/fmicb.2015.00738, 2015.

Fawcett, S. E., Ward, B. B., Lomas, M. W., and Sigman, D. M.: Vertical decoupling of nitrate assimilation and nitrification in the Sargasso Sea, Deep-Sea Res. Pt. I, 103, 64-72, 2015.

Fernand, L., Weston, K., Morris, T., Greenwood, N., Brown, J., and Jickells, T.: The contribution of the deep chlorophyll maximum to primary production in a seasonally stratified shelf sea, the North Sea, Biogeochemistry, 113, 153-166, https://doi.org/10.1007/s10533-013-9831-7, 2013.

From, N., Richardson, K., Mousing, E. A., and Jensen, P. E.: Removing the light history signal from normalized variable fluorescence $(\mathrm{Fv} / \mathrm{Fm})$ measurements on marine phytoplankton, Limnol. Oceanogr.-Meth., 12, 776-783, 2014.

Frouin, R., McPherson, J., Ueyoshi, K., and Franz, B. A.: A time series of photosynthetically available radiation at the ocean surface from SeaWiFS and MODIS data, Proc. SPIE, 8525, 852519, https://doi.org/10.1117/12.981264, 2012.

Gattuso, J.-P., Frankignoulle, M., and Wollast, R.: Carbon and carbonate metabolism in coastal aquatic ecosystems, Annual Reviews of Ecological Systems, 29, 405-434, 1998.

Grasshoff, K., Erhardt, M., and Kremling, K.: Methods of seawater analysis, 2. Revision, Verlag Chemie, Weinheim, 1983.

Hansen, J. L. S. and Bendtsen, J.: Seasonal bottom water respiration in the North Sea-Baltic Sea transition zone: rates, temperature 
sensitivity and sources of organic material, Mar. Ecol.-Prog. Ser., 499, 19-34, 2014.

Hickman, A. E., Moore, C. M., Sharples, J., Lucas, M. I., Tilstone, G. H., Krivtsov, V., Holligan, P. M.: Primary production and nitrate uptake within the seasonal thermocline of a stratified shelf sea, Mar. Ecol.-Prog. Ser., 463, 39-57, 2012.

Holt, J. and Proctor, R.: The seasonal circulation and volume transport on the northwest European continental shelf: A fine-resolution model study, J. Geophys. Res., 113, C06021, https://doi.org/10.1029/2006JC004034, 2008.

Holt, J., Wakelin, S., Lowe, J., and Tinker, J.: The potential impacts of climate change on the hydrography of the northwest European continental shelf, Prog. Oceanogr., 86, 361-379, 2010.

Holt, J., Butenschön, M., Wakelin, S. L., Artioli, Y., and Allen, J. I.: Oceanic controls on the primary production of the northwest European continental shelf: model experiments under recent past conditions and a potential future scenario, Biogeosciences, 9, 97-117, https://doi.org/10.5194/bg-9-97-2012, 2012.

Hu, C., Lee, Z., and Franz, B. A.: Chlorophyll-a algorithms for oligotrophic oceans: A novel approach based on threeband reflectance difference, J. Geophys. Res., 117, C01011, https://doi.org/10.1029/2011JC007395, 2012.

Huthnance, J. M.: Circulation, exchange and water masses at the ocean margin: the role of physical processes at the shelf edge, Prog. Oceanogr., 35, 353-431, 1995.

ICES: Report of the ICES Advisory Committee 2008, Book 6: North Sea, International Council for the Exploration of the Sea (ICES), 2008

IOC, SCOR and IAPSO: The international thermodynamic equation of seawater - 2010: Calculation and use of thermodynamic properties, Intergovernmental Oceanographic Commission, Manuals and Guides No. 56, UNESCO (English), 196 pp., 2010.

Kumari, B.: Comparison of high performance liquid chromatography and fluorometri ocean colour pigments, J. Indian Soc. Remot., 33, 541-546, 2005.

Lueck, R.: Calculating the rate of dissipation of turbulent kinetic energy, RSI Technical Note 028, Rockland Scientific International, Victoria, Canada, 18 pp., 2016.

McKee, D., Röttgers, R., Neukermans, G., Calzado, V. S., Trees, C., Ampolo-Rella, M., Neil, C., and Cunningham, A.: Impact of measurement uncertainties on determination of chlorophyll-specific absorption coefficient for marine phytoplankton, J. Geophys. Res.-Oceans, 119-925, 9013-9025, https://doi.org/10.1002/2014JC009909, 2014.

Osborn, T. R.: Estimate of the local rate of vertical diffusion from dissipation measurements, J. Phys. Oceanogr., 10, 83-89, 1980.

Pätsch, J. and Kühn, W.: Nitrogen and carbon cycling in the North Sea and exchange with the North Atlantic - A model study. Part I. Nitrogen budget and fluxes, Cont. Shelf Res., 28, 767-787, 2008.

Pätsch, J., Burchard, H., Dieterich, C., Gräwe, U., Gröger, M., Mathis, M., Kapitza, H., Bersch, M., Moll, A., Pohlmann, T., Su, J., Ho-Hagemann, Ha T. M., Schulz, A. Elizalde, A., and Eden, C.: An evaluation of the North Sea circulation in global and regional models relevant for ecosystem simulations, Ocean Model., 116, 70-95, 2017.

Platt, T., Gallegos, C. L., and Harrison, W. G.: Photoinhibation of photosynthesis in natural assemblages of marine phytoplankton, J. Mar. Res., 38, 687-701, 1980.
Press, W. H., Teukolsky, S. A., Vetterling, W. T., and Flannery, B. P.: Numerical Recipes in FORTRAN: The Art of Scientific Computing, Press Syndicate of the University of Cambridge, USA, 1992.

Raven, J. A. and Richardson, K.: Dinophyte flagella: a cost-benefit analysis, New Phytol., 98, 259-276, 1984.

Redfield, A. C., Ketchum, B. H., and Richards, F. A.: The influence of organisms on the composition of sea water, in: The Sea, edited by: Hill, M. N., Wiley-Interscience, New Yourk, 26-77, 1963.

Richardson, K., Visser, A. W., and Pedersen, F. B.: Subsurface phytoplankton blooms fuel pelagic production in the North Sea, J. Plankton Res., 22, 1663-1671, 2000.

Richardson, K., Bendtsen, J., Kragh, T., and Mousing, E. A.: Constraining the distribution of photosynthetic parameters in the global ocean, Front. Mar. Sci., 3, 269, https://doi.org/10.3389/fmars.2016.00269, 2016.

Røed, L. P. and Fossum, I.: Mean and eddy motion in the Skagerrak/northern North Sea: insight from a numerical model, Ocean Dynam., 54, 197-220, https://doi.org/10.1007/s10236003-0076-1, 2004.

Scott, B. E., Sharples, J., Ross, O. N., Wang, J., Pierce, G. J., and Camphuysen, C. J.: Sub-surface hotspots in shallow seas: finescale limited locations of top predator foraging habitat indicated by tidal mixing and sub-surface chlorophyll, Mar. Ecol.-Prog. Ser., 408, 207-226, https://doi.org/10.3354/meps08552, 2010.

Sharples, J., Moore, C. M., Rippeth, T. P., Holligan, P. M., Hydes, D. J., Fisher, N. R., and Simpson, J. H.: Phytoplankton distribution and survival in the thermocline, Limnol. Oceanogr., 46, 486-496, 2001.

Sharples, J., Tweddle, J. F., Green, J. A. M., Palmer, M. R., Kim, Y.N., Hickman, A. E., Holligan, P. M., Moore, C. M., Rippeth, T. P., Simpson, J. H., and Krivtsov, V.: Spring-Neap Modulation of Internal Tide Mixing and Vertical Nitrate Fluxes at a Shelf Edge in Summer, Limnol. Oceanogr., 52, 1735-1747, 2007.

Sharples, J., Moore, C. M., Hickman, A. E., Holligan, P. M., Tweddle, J. F., Palmer, M. R., and Simpson, J. H.: Internal tidal mixing as a control on continental margin ecosystems, Geophys. Res. Lett., 36, L23603, https://doi.org/10.1029/2009GL040683, 2009.

Sharples, J., Ellis, J. R., Nolan, G., and Scott, B. E.: Fishing and the oceanography of a stratified shelf sea, Progr. Oceanogr., 117, 130-139, 2013.

Shih, L. H., Koseff, J. R., Ivey, G. N., and Ferziger, J. H.; Parameterization of turbulent fluxes and scales using homogeneous sheared stably stratified turbulence simulations, J. Fluid. Mech., 525, 193-214, https://doi.org/10.1017/S0022112004002587, 2005.

Simpson, J. and Sharples, J.: Introduction to the physical and biological oceanography of shelf seas, Cambridge, Cambridge University Press, 424 pp., 2012.

Skogen, M. D. and Moll, A.: Interannual variability of the North Sea primary production: comparison from two model studies, Cont. Shelf Res., 20, 129-151, 2000.

Tweddle, J. F., Sharples, J., Palmer, M. R., Davidson, K., and McNeill, S.: Enhanced nutrient fluxes at the shelf sea seasonal thermocline caused by stratified flow over a bank, Progr. Oceanogr., 117, 37-47, 2013.

Volk, T. and Hoffert, M. I.: Ocean carbon pumps: Analysis of relative strengths and efficiencies in ocean-driven atmospheric $\mathrm{CO}_{2}$, in: The Carbon Cycle and Atmospheric $\mathrm{CO}_{2}$ : Natural Variations Archean to Present, Geophysical Monograph Series, Vol. 32. 
edited by: Sundquist, E. T. and Broecker, W. S., AGU, Washington, DC, 99-110, 1985.

Webb, W. L., Newton, M., and Starr, D.: Carbon dioxide exchange of Alnus rubra. A mathematical model, Oecologia, 17, 281-291, 1974.

Weston, K., Fernand, L., Mills, D. K., Delahunty, R., and Brown, J.: Primary production in the deep chlorophyll maximum of the central North Sea, J. Plankton Res., 27, 909-922, 2005.

Williams, C., Sharples, J., Mahaffey, C., and Rippeth, T.: Winddriven nutrient pulses to the subsurface chlorophyll maximum in seasonally stratified shelf seas, Geophys. Res. Lett., 40, 54675472, https://doi.org/10.1002/2013GL058171, 2013.
Winther, N. G. and Johannessen, J. A.: North Sea circulation: Atlantic inflow and its destination, J. Geophys. Res., 111, C12018, https://doi.org/10.1029/2005JC003310, 2006.

Wolk, F., Yamazaki, H., Seuront, L., and Lueck, R. G.: A new freefall profiler for measuring bio-physical microstructure, J. Atmos. Ocean. Tech., 19, 780-793, 2002.

Yool, A., Martin, A. P., Fernández, C., and Clark, D. R.: The significance of nitrification for oceanic new production, Nature, 447, 999-1002, 2007.

Zehr, J. P. and Kudela, R. M.: Nitrogen cycle of the open ocean: From genes to ecosystems, Annu. Rev. Mar. Sci., 3, 197-225, 2011. 